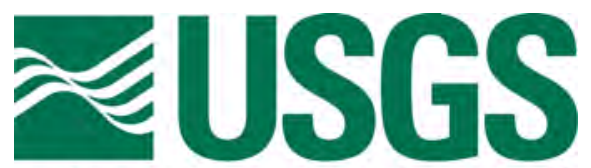

science for a changing world

\title{
Ground- and Surface-Water Chemistry of Handcart Gulch, Park County, Colorado, 2003-2006
}

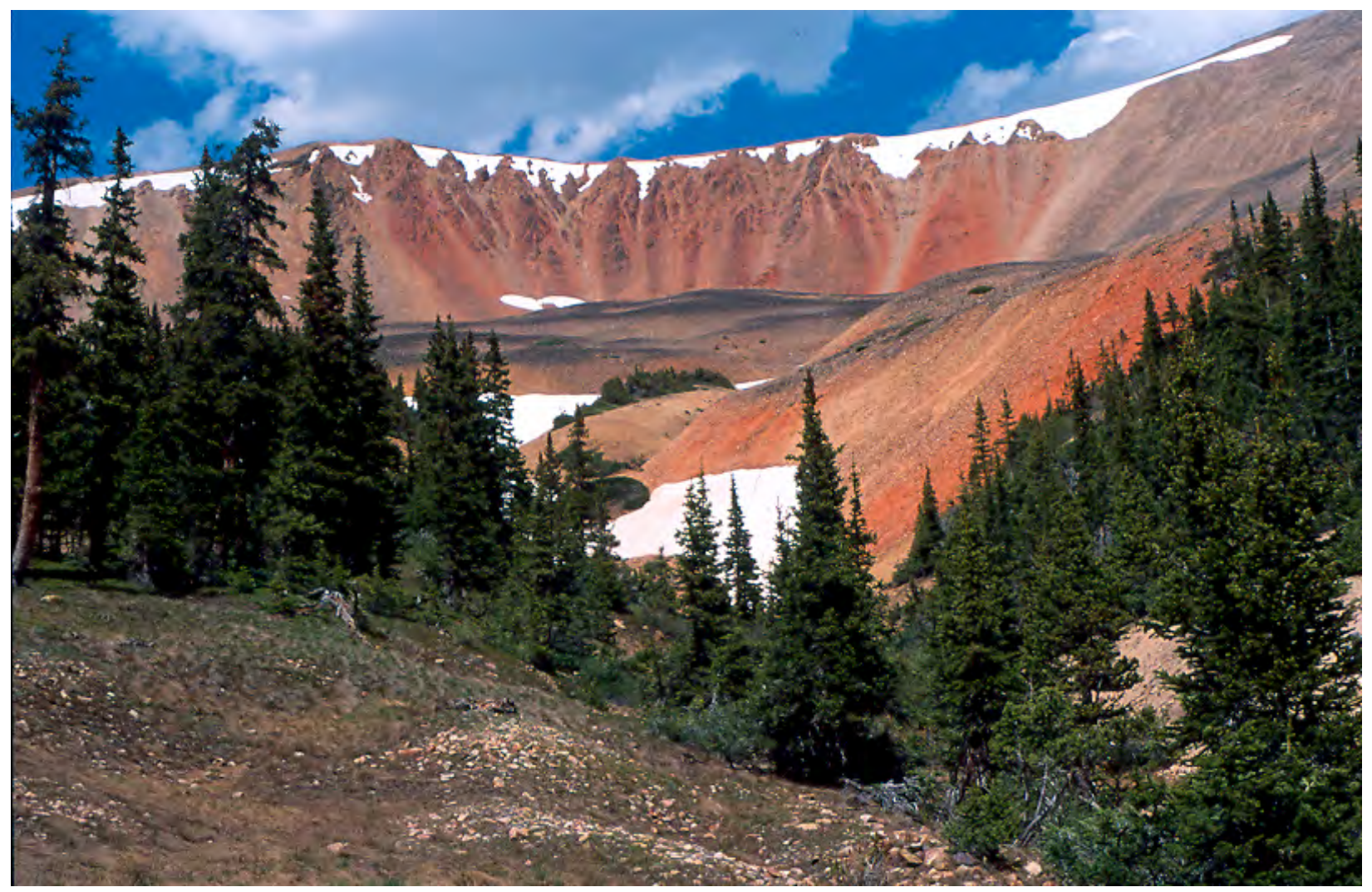

Open-File Report 2007-1020

U.S. Department of the Interior

U.S. Geological Survey 
Front cover: Photograph of Handcart Gulch showing the Continental Divide in the upper portion of the image, the rock glacier in the middle of the image, and the trunk stream in the lower right. 


\section{Ground- and Surface-Water Chemistry of Handcart Gulch, Park County, Colorado, 2003-2006}

By Philip L. Verplanck, Andrew H. Manning, Briant A. Kimball, R. Blaine McCleskey, Robert L. Runkel, Jonathan Saul Caine, Monique Adams, Pamela A. Gemery-Hill, and David L. Fey

Open-File Report 2007-1020

U.S. Department of the Interior U.S. Geological Survey 


\section{U.S. Department of the Interior DIRK KEMPTHORNE, Secretary}

\section{U.S. Geological Survey Mark D. Myers, Director}

U.S. Geological Survey, Reston, Virginia 2008

For product and ordering information:

World Wide Web: http://www.usgs.gov/pubprod

Telephone: 1-888-ASK-USGS

For more information on the USGS-the Federal source for science about the Earth, its natural and living resources, natural hazards, and the environment: World Wide Web: http://www.usgs.gov

Telephone: 1-888-ASK-USGS

Suggested citation:

Verplanck, P.L., Manning, A.H., Kimball, B.A., McCleskey, R.B., Runkel, R.L., Caine, J.S., Adams, Monique, Gemery-Hill, P.A., and Fey, D.L., 2008, Ground- and surfacewater chemistry of Handcart Gulch, Park County, Colorado, 2003-2006: U.S. Geological Survey Open-File Report 2007-1020, 31 p.

Any use of trade, product, or firm names is for descriptive purposes only and does not imply endorsement by the U.S. Government.

Although this report is in the public domain, permission must be secured from the individual copyright owners to reproduce any copyrighted material contained within this report. 


\section{Contents}

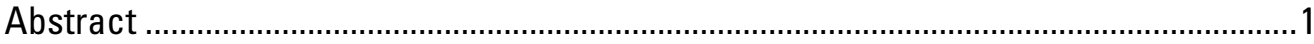

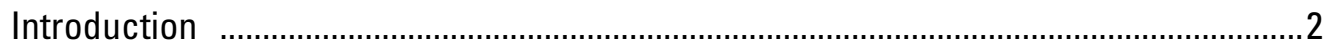

Purpose and Scope ...................................................................................................

Physical Description of the Study Area .........................................................................

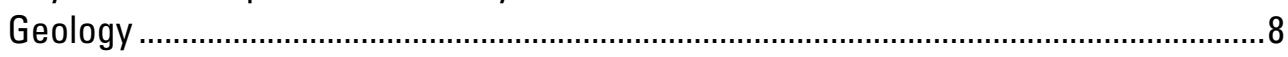

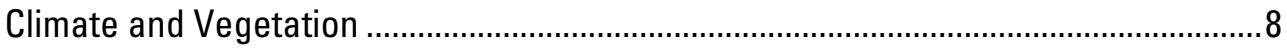

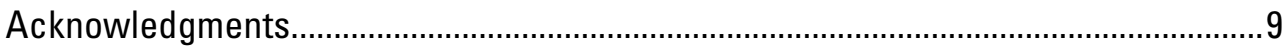

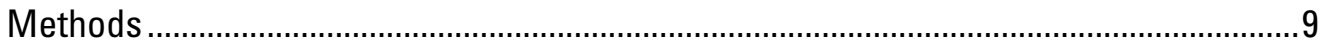

Sampling Sites ………………………………………………………………….....

Water-Chemistry Sampling.......................................................................................... 10

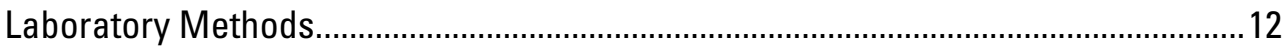

Quality Assurance and Quality Control .................................................................... 15

Water Chemistry........................................................................................................ 17

References Cited …………....................................................................................... 29

\section{Figures}

1. Map of central and western Colorado showing location of Colorado mineral belt and study area ..........................................................................

2. Map of Handcart Gulch showing well locations ..........................................................

3. Map of Handcart Gulch showing tracer synoptic sampling locations...........................5

4. Comparison of analytical results by ICP-AES and ICP-MS ........................................ 16

5. $\mathrm{pH}$ in relation to dissolved sulfate concentration for ground- and surface-water samples in Handcart Gulch.......................................................22

6. $\mathrm{pH}$ as a function of downstream distance for Handcart Gulch...................................22

7. Dissolved sulfate concentration as a function of downstream distance for Handcart Gulch .....................................................................................2

8. Dissolved and total-recoverable iron concentration as a function of downstream distance for Handcart Gulch.........................................................24

9. Dissolved and total-recoverable copper concentration as a function of downstream distance for Handcart Gulch......................................................22

10. Dissolved and total-recoverable zinc concentration as a function of downstream distance for Handcart Gulch........................................................26

11. Discharge as a function of downstream distance for Handcart Gulch .....................27

12. Constituent loads as a function of downstream distance for Handcart

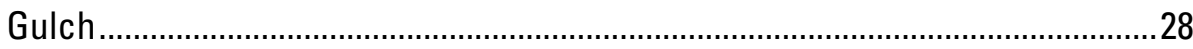

\section{Tables}

1. Locations of well- and surface-water sampling sites .................................................

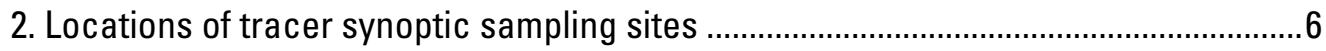

3. Sample container preparation and stabilization methods for samples ......................11

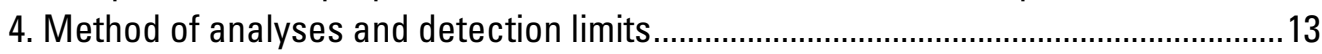

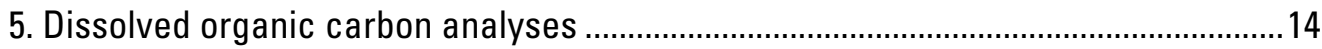

6. Water analyses of ground-water study samples .................................... link to table

7. ICP-MS analyses of ground-water study samples...................................... link to table 
8. Water analyses of synoptic tracer study samples. link to table

9. ICP-MS analyses of synoptic tracer study samples .................................... link to table

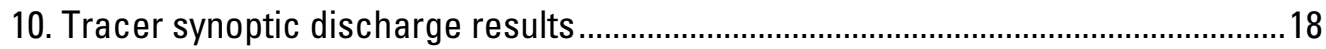

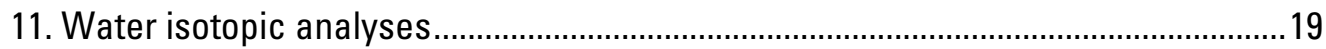

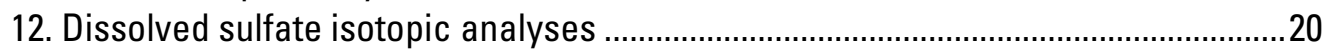




\section{Ground- and Surface-Water Chemistry of Handcart Gulch, Park County, Colorado, 2003-2006}

\section{Abstract}

As part of a multidisciplinary project to determine the processes that control ground-water chemistry and flow in mineralized alpine environments, ground- and surface-water samples from Handcart Gulch, Colorado were collected for analysis of inorganic solutes and water and dissolved sulfate stable isotopes in selected samples. The primary aim of this study was to document variations in ground-water chemistry in Handcart Gulch and to identify changes in water chemistry along the receiving stream of Handcart Gulch.

Water analyses are reported for ground-water samples collected from 12 wells in Handcart Gulch, Colorado. Samples were collected between August 2003 and October 2005. Water analyses for surface-water samples are reported for 50 samples collected from Handcart Gulch and its inflows during a low-flow tracer injection on August 6, 2003. In addition, water analyses are reported for three other Handcart Gulch stream samples collected in September 2005 and March 2006. Reported analyses include field parameters ( $\mathrm{pH}$, specific conductance, temperature, dissolved oxygen, and $\mathrm{Eh}$ ), major and trace constituents, oxygen and hydrogen isotopic composition of water and oxygen and sulfur isotopic composition of dissolved sulfate.

Ground-water samples from this study are $\mathrm{Ca}-\mathrm{SO}_{4}$ type and range in $\mathrm{pH}$ from 2.5 to 6.8. Most of the samples (75 percent) have $\mathrm{pH}$ values between 3.3 and 4.3. Surface water samples are also $\mathrm{Ca}-\mathrm{SO}_{4}$ type and have a narrower range in $\mathrm{pH}$ (2.7-4.0). Groundand surface-water samples vary from relatively dilute (specific conductance of $68 \mu \mathrm{S} / \mathrm{cm}$ ) to concentrated (specific conductance of $2,000 \mu \mathrm{S} / \mathrm{cm}$ ). 


\section{Introduction}

Handcart Gulch, an alpine watershed located along the Continental Divide in the southeastern portion of the Montezuma Mining District of the central Colorado Rocky Mountain Front Range, contains an unmined, porphyry-related molybdenite exploration target (fig. 1). Process-related studies by U.S. Geological Survey (USGS) scientists and collaborators were undertaken to determine the controls of ground-water chemistry and flow in this mineralized alpine environment (Caine and others, 2004; Manning and others, 2004; Verplanck and others, 2004; Kahn and others, 2005; Kahn, 2005; Caine and others, 2006). Understanding the natural variation of water chemistry in ground and surface water in mineralized alpine watersheds is important because it provides estimates of premining water quality in historically mined areas with similar geology and climate, as well as providing insight into the fundamental processes that liberate, transport, and deposit constituents that may degrade water quality. Also, chemical data can provide additional constraints when creating ground-water flow models.

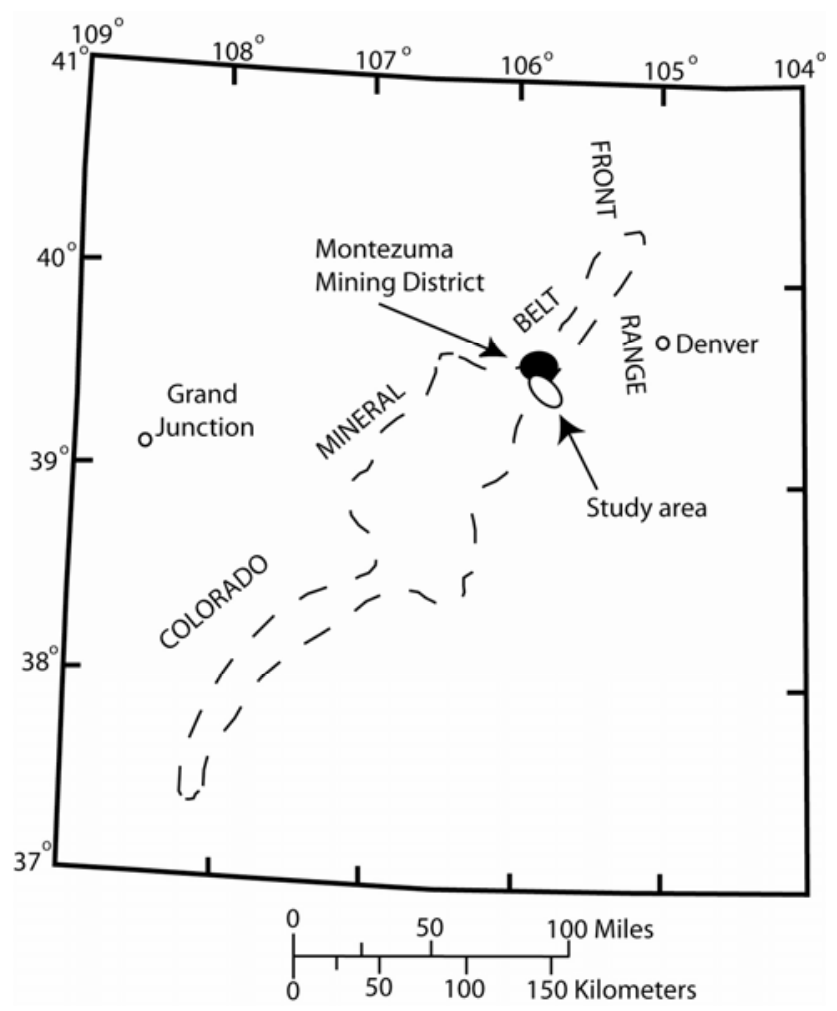

Figure 1. Map of central and western Colorado showing location of Colorado mineral belt and study area. 
In the summers of 2001 and 2002, four wells in Handcart Gulch were drilled as mineral exploration boreholes by Mineral Systems, Inc. They were drilled in the upper portions of the watershed; one at Webster Pass on the Continental Divide at 3,688 $\mathrm{m}$ and range in depth from 365 to 1,065 m (fig. 2). In 2003 and 2004 Mineral Systems Inc. donated the boreholes to the U.S. Geological Survey, and the U.S. Geological Survey reconditioned three of the boreholes for use as scientific research monitoring wells. In the fall of 2003 the deep wells were supplemented by the drilling of nine new shallow wells (3-52 m deep) in the vicinity of the trunk stream of Handcart Gulch (fig. 2, table 1). Detailed descriptions of well construction, lithology, and water-level data and an overview of other research investigations were reported in Caine and others (2006). Water from three of the exploration boreholes and the nine shallower wells was sampled periodically between August 2003 and October 2005.

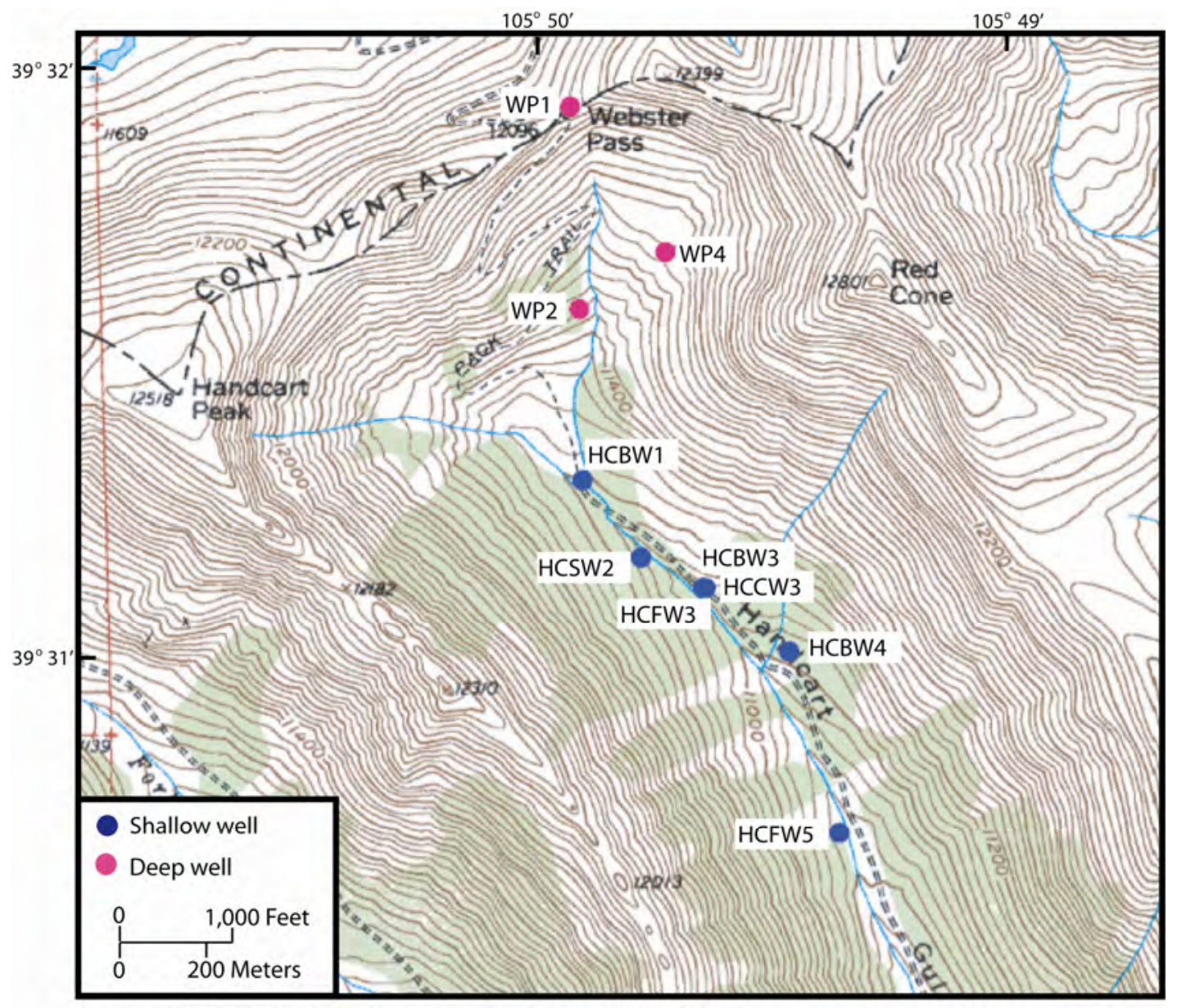

Base from U.S. Geological Survey Montezuma Quadrangle, 1:24,000 (1958)

Figure 2. Map of Handcart Gulch showing well locations. 
Table 1. Locations of well- and surface-water sampling sites.

[m, meters; HCG, Handcart Gulch; SW, southwest]

\begin{tabular}{ccccc}
\hline SAMPLE NUMBER & LATITUDE & LONGITUDE & LOCATION & ELEVATION' (m) \\
\hline Wells & & & & \\
WP1 & $39^{\circ} 31^{\prime} 51^{\prime \prime}$ & $105^{\circ} 49^{\prime} 57^{\prime \prime}$ & Webster Pass & 3687 \\
WP2 & $39^{\circ} 31^{\prime} 34^{\prime \prime}$ & $105^{\circ} 49^{\prime} 53^{\prime \prime}$ & Sub-basin SW of rock glacier & 3507 \\
WP4 & $39^{\circ} 31^{\prime} 40^{\prime \prime}$ & $105^{\circ} 49^{\prime} 43^{\prime \prime}$ & On rock glacier & 3570 \\
HCBW1 & $39^{\circ} 31^{\prime} 18.3^{\prime \prime} 105^{\circ} 49^{\prime} 52.6^{\prime \prime}$ & See figure 2 & 3415 \\
HCSW1 & $39^{\circ} 31^{\prime} 18.4^{\prime \prime} 105^{\circ} 49^{\prime} 52.8^{\prime \prime}$ & See figure 2 & 3415 \\
HCBW2 & $39^{\circ} 31^{\prime} 11.2^{\prime \prime} 105^{\circ} 49^{\prime} 42.7^{\prime \prime}$ & See figure 2 & 3393 \\
HCSW2 & $39^{\circ} 31^{\prime} 11.2^{\prime \prime} 105^{\circ} 49^{\prime} 42.7^{\prime \prime}$ & See figure 2 & 3393 \\
HCBW3 & $39^{\circ} 31^{\prime} 08.4^{\prime \prime} 105^{\circ} 49^{\prime} 37.7^{\prime \prime}$ & See figure 2 & 3377 \\
HCFW3 & $39^{\circ} 31^{\prime} 08.4^{\prime \prime} 105^{\circ} 49^{\prime} 37.7^{\prime \prime}$ & See figure 2 & 3377 \\
HCCW3 & $39^{\circ} 31^{\prime} 08.4^{\prime \prime} 105^{\circ} 49^{\prime} 37.7^{\prime \prime}$ & See figure 2 & 3377 \\
HCBW4 & $39^{\circ} 31^{\prime} 02.5^{\prime \prime} 105^{\circ} 49^{\prime} 27.6^{\prime \prime}$ & See figure 2 & 3360 \\
HCFW5 & $39^{\circ} 30^{\prime} 45.7^{\prime \prime} 105^{\circ} 49^{\prime} 19.9^{\prime \prime}$ & See figure 2 & 3302 \\
Surface Water & & & & \\
HCG1 & $39^{\circ} 31^{\prime} 18.3^{\prime \prime}$ & $105^{\circ} 49^{\prime} 52.6^{\prime \prime}$ & HCG adjacent to HCBW1 & 3415 \\
HCG5 & $39^{\circ} 30^{\prime} 45.7^{\prime \prime}$ & $105^{\circ} 49^{\prime} 19.9^{\prime \prime}$ & HCG adjacent to HCBW5 & 3302 \\
\hline
\end{tabular}

${ }^{1}$ Land surface altitude

To evaluate the variation in flow and chemistry of the receiving stream of Handcart Gulch, a tracer injection and synoptic sampling study was undertaken in August 2003. Along the upper two kilometers of Handcart Gulch, 27 stream samples and 23 inflow samples were collected (fig. 3, table 2). Water chemistry and stream-flow data were used to calculate chemical loads from surface and subsurface flow (Kimball and others, 1999). In mountain streams a substantial amount of water can flow through the streambed or hyporheic zone, making it difficult to accurately measure streamflow with traditional velocity measurements within the stream channel. Tracer-injection methods are a reliable way to quantify total streamflow by using changes in concentration of a tracer $(\mathrm{LiBr})$ injected at a constant rate and assuming conservation of mass (Kimball and others, 2002). 


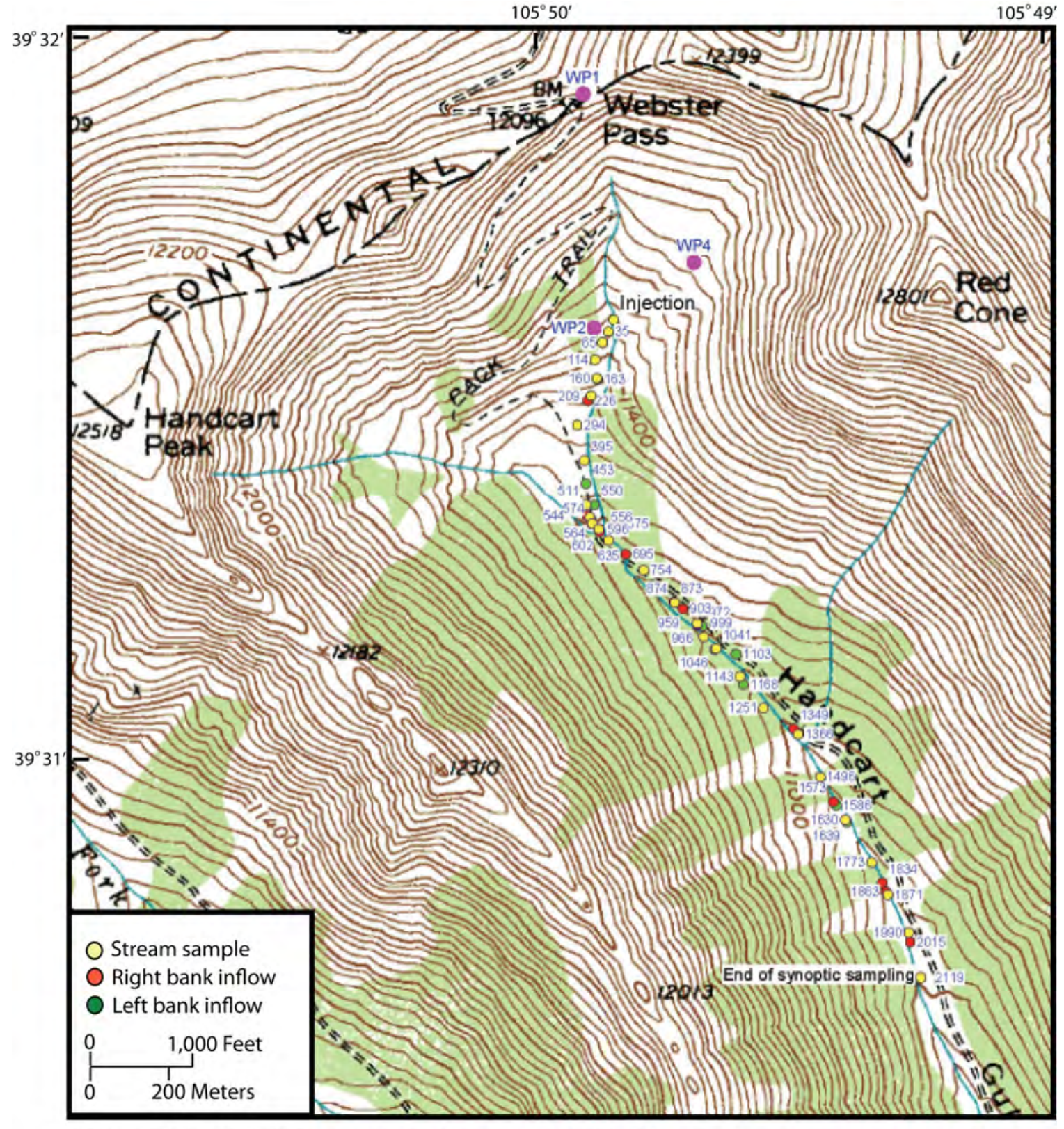

Base from U.S. Geological Survey Montezuma Quadrangle, 1:24,000 (1958)

Figure 3. Map of Handcart Gulch showing tracer synoptic sampling locations. 
Table 2. Locations of tracer synoptic sampling sites.

[ID, identification; HCG, Handcart Gulch; LBI, left bank inflow; RBI, right bank inflow; m, meters; T, transport]

\begin{tabular}{|c|c|c|c|c|}
\hline Sample ID & $\begin{array}{l}\text { Distance } \\
(\mathrm{m})\end{array}$ & Site description & Latitude & Longitude \\
\hline $\mathrm{HC}-0$ & 0 & $\begin{array}{l}\text { T0 site - HCG upstream from injection, end of rock } \\
\text { glacier }\end{array}$ & $39^{\circ} 31^{\prime} 34.896^{\prime \prime}$ & $105^{\circ} 49^{\prime} 51.132^{\prime \prime}$ \\
\hline HC-35 & 35 & HCG below injection & $39^{\circ} 31^{\prime} 33.924^{\prime \prime}$ & $105^{\circ} 49^{\prime} 51.672^{\prime \prime}$ \\
\hline HC-65 & 65 & HCG at top of cliff with waterfall & $39^{\circ} 31^{\prime} 33.06^{\prime \prime}$ & $105^{\circ} 49^{\prime} 52.248^{\prime \prime}$ \\
\hline HC-144 & 114 & HCG downstream from waterfall & $39^{\circ} 31^{\prime} 31.692^{\prime \prime}$ & $105^{\circ} 49^{\prime} 53.004^{\prime \prime}$ \\
\hline HC-160 & 160 & HCG upstream from LBI at toe of rock glacier & $39^{\circ} 31^{\prime} 30.216^{\prime \prime}$ & $105^{\circ} 49^{\prime} 52.824^{\prime \prime}$ \\
\hline HC-163 & 163 & LBI - toe of upper rock glacier & $39^{\circ} 31^{\prime} 30.144^{\prime \prime}$ & $105^{\circ} 49^{\prime} 52.752^{\prime \prime}$ \\
\hline HC-209 & 209 & HCG downstsream from rock glacier inflows & $39^{\circ} 31^{\prime} 28.812^{\prime \prime}$ & $105^{\circ} 49^{\prime} 53.4^{\prime \prime}$ \\
\hline HC-226 & 226 & RBI - pond on right bank & $39^{\circ} 31^{\prime} 28.416^{\prime \prime}$ & $105^{\circ} 49^{\prime} 53.724^{\prime \prime}$ \\
\hline HC-294 & 294 & HCG below inflows & $39^{\circ} 31^{\prime} 26.436^{\prime \prime}$ & $105^{\circ} 49^{\prime} 54.804^{\prime \prime}$ \\
\hline HC-395 & 395 & HCG stream site & $39^{\circ} 31^{\prime} 23.628^{\prime \prime}$ & $105^{\circ} 49^{\prime} 54.012^{\prime \prime}$ \\
\hline $\mathrm{HC}-453$ & 453 & LBI - pond has stream water & $39^{\circ} 31^{\prime} 21.756^{\prime \prime}$ & $105^{\circ} 49^{\prime} 53.832^{\prime \prime}$ \\
\hline HC-511 & 511 & HCG upstream from iron bog area and inflows & $39^{\circ} 31^{\prime} 20.064^{\prime \prime}$ & $105^{\circ} 49^{\prime} 53.796^{\prime \prime}$ \\
\hline HC-544 & 544 & RBI - small inflow & $39^{\circ} 31^{\prime} 19.2^{\prime \prime}$ & $105^{\circ} 49^{\prime} 53.688^{\prime \prime}$ \\
\hline $\mathrm{HC}-550$ & 550 & LBI - draining from bushes & $39^{\circ} 31^{\prime} 20.064^{\prime \prime}$ & $105^{\circ} 49^{\prime} 52.932^{\prime \prime}$ \\
\hline HC-556 & 556 & HCG downstream from iron-free inflows & $39^{\circ} 31^{\prime} 19.056^{\prime \prime}$ & $105^{\circ} 49^{\prime} 53.4^{\prime \prime}$ \\
\hline HC-564 & 564 & LBI - drains iron bog & $39^{\circ} 31^{\prime} 18.84^{\prime \prime}$ & $105^{\circ} 49^{\prime} 53.22^{\prime \prime}$ \\
\hline $\mathrm{HC}-574$ & 574 & HCG pool on ferricrete at bottom of chute & $39^{\circ} 31^{\prime} 18.552^{\prime \prime}$ & $105^{\circ} 49^{\prime} 53.148^{\prime \prime}$ \\
\hline HC-575 & 575 & RBI - draining iron bog & $39^{\circ} 31^{\prime} 18.516^{\prime \prime}$ & $105^{\circ} 49^{\prime} 53.184^{\prime \prime}$ \\
\hline HC-596 & 596 & $\begin{array}{l}\text { T1 site - HCG upstream from small inflow on right } \\
\text { bank }\end{array}$ & $39^{\circ} 31^{\prime} 18.12^{\prime \prime}$ & $105^{\circ} 49^{\prime} 52.464^{\prime \prime}$ \\
\hline HC-602 & 602 & RBI - main tributary from Handcart Peak subbasin & $39^{\circ} 31^{\prime} 17.904^{\prime \prime}$ & $105^{\circ} 49^{\prime} 52.392^{\prime \prime}$ \\
\hline HC-635 & 635 & HCG downstream from RBI & $39^{\circ} 31^{\prime} 17.22^{\prime \prime}$ & $105^{\circ} 49^{\prime} 51.456^{\prime \prime}$ \\
\hline HC-695 & 695 & RBI - drains from rock face & $39^{\circ} 31^{\prime} 16.104^{\prime \prime}$ & $105^{\circ} 49^{\prime} 49.656^{\prime \prime}$ \\
\hline HC-754 & 754 & HCG downstream from chutes in ferricrete & $39^{\circ} 31^{\prime} 14.844^{\prime \prime}$ & $105^{\circ} 49^{\prime} 47.784^{\prime \prime}$ \\
\hline HC-873 & 873 & HCG upstream from LBI from ferricrete & $39^{\circ} 31^{\prime} 12.252^{\prime \prime}$ & $105^{\circ} 49^{\prime} 44.544^{\prime \prime}$ \\
\hline HC-874 & 874 & LBI - drains left bank rock glacier & $39^{\circ} 31^{\prime} 12.288^{\prime \prime}$ & $105^{\circ} 49^{\prime} 44.616^{\prime \prime}$ \\
\hline HC-903 & 903 & RBI - small hole in ferricrete & $39^{\circ} 31^{\prime} 11.748^{\prime \prime}$ & $105^{\circ} 49^{\prime} 43.68^{\prime \prime}$ \\
\hline HC-959 & 959 & HCG upstream from RBI & $39^{\circ} 31^{\prime} 10.596^{\prime \prime}$ & $105^{\circ} 49^{\prime} 42.204^{\prime \prime}$ \\
\hline HC-966 & 966 & RBI - drains bog across road & $39^{\circ} 31^{\prime} 10.38^{\prime \prime}$ & $105^{\circ} 49^{\prime} 42.168^{\prime \prime}$ \\
\hline HC-972 & 972 & LBI - drains toe of rock glacier, sample pit & $39^{\circ} 31^{\prime} 10.38^{\prime \prime}$ & $105^{\circ} 49^{\prime} 41.7^{\prime \prime}$ \\
\hline HC-999 & 999 & HCG along the rock glacier & $39^{\circ} 31^{\prime} 9.516^{\prime \prime}$ & $105^{\circ} 49^{\prime} 41.484^{\prime \prime}$ \\
\hline HC-1041 & 1041 & HCG upstream from LBI & $39^{\circ} 31^{\prime} 8.58^{\prime \prime}$ & $105^{\circ} 49^{\prime} 40.224^{\prime \prime}$ \\
\hline HC-1046 & 1046 & LBI - small inflow from rock glacier & $39^{\circ} 31^{\prime} 8.508^{\prime \prime}$ & $105^{\circ} 49^{\prime} 40.368^{\prime \prime}$ \\
\hline HC-1103 & 1103 & LBI - Pool near end of glacier that drains to stream & $39^{\circ} 31^{\prime} 8.148^{\prime \prime}$ & $105^{\circ} 49^{\prime} 38.136^{\prime \prime}$ \\
\hline HC-1143 & 1143 & HCG downstream from lower rock glacier inflows & $39^{\circ} 31^{\prime} 6.348^{\prime \prime}$ & $105^{\circ} 49^{\prime} 37.704^{\prime \prime}$ \\
\hline HC-1168 & 1168 & LBI - small inflow at base of boulder & $39^{\circ} 31^{\prime} 5.7^{\prime \prime}$ & $105^{\circ} 49^{\prime} 37.38^{\prime \prime}$ \\
\hline $\mathrm{HC}-1251$ & 1251 & HCG at end of reach with little visible inflow & $39^{\circ} 31^{\prime} 3.828^{\prime \prime}$ & $105^{\circ} 49^{\prime} 35.256^{\prime \prime}$ \\
\hline $\mathrm{HC}-1349$ & 1349 & RBI - draining along cascading reach & $39^{\circ} 31^{\prime} 2.172^{\prime \prime}$ & $105^{\circ} 49^{\prime} 32.124^{\prime \prime}$ \\
\hline HC-1366 & 1366 & HCG on ferricrete bed with chutes and cascades & $39^{\circ} 31^{\prime} 1.74^{\prime \prime}$ & $105^{\circ} 49^{\prime} 31.656^{\prime \prime}$ \\
\hline HC-1496 & 1496 & HCG downstream from small seeps & $39^{\circ} 30^{\prime} 58.32^{\prime \prime}$ & $105^{\circ} 49^{\prime} 29.316^{\prime \prime}$ \\
\hline HC-1573 & 1573 & RBI - from avalanche fan & $39^{\circ} 30^{\prime} 56.34^{\prime \prime}$ & $105^{\circ} 49^{\prime} 27.948^{\prime \prime}$ \\
\hline HC-1586 & 1586 & LBI - draining from bushes & $39^{\circ} 30^{\prime} 56.052^{\prime \prime}$ & $105^{\circ} 49^{\prime} 27.624^{\prime \prime}$ \\
\hline
\end{tabular}


Table 2. Locations of tracer synoptic sampling sites-Continued.

[ID, identification; HCG, Handcart Gulch; LBI, left bank inflow; RBI, right bank inflow; m, meters; T, transport]

\begin{tabular}{lllll}
\hline Sample ID & $\begin{array}{c}\text { Distance } \\
(\mathbf{m})\end{array}$ & \multicolumn{1}{c}{ Site description } & \multicolumn{1}{c}{ Latitude } & \multicolumn{1}{c}{ Longitude } \\
\hline HC-1630 & 1630 & HCG at narrow spot in ferricrete & $39^{\circ} 30^{\prime} 54.9^{\prime \prime}$ & $105^{\circ} 49^{\prime} 26.688^{\prime \prime}$ \\
HC-1639 & 1639 & LBI - small stream inflow & $39^{\circ} 30^{\prime} 54.684^{\prime \prime}$ & $105^{\circ} 49^{\prime} 26.508^{\prime \prime}$ \\
HC-1773 & 1773 & HCG downstream from bog area on right bank & $39^{\circ} 30^{\prime} 51.48^{\prime \prime}$ & $105^{\circ} 49^{\prime} 23.916^{\prime \prime}$ \\
HC-1834 & 1834 & RBI - small inflow & $39^{\circ} 30^{\prime} 49.824^{\prime \prime}$ & $105^{\circ} 49^{\prime} 22.8^{\prime \prime}$ \\
HC-1863 & 1863 & RBI - pond on right bank near iron bog & $39^{\circ} 30^{\prime} 49.104^{\prime \prime}$ & $105^{\circ} 49^{\prime} 22.404^{\prime \prime}$ \\
HC-1871 & 1871 & T2 site - HCG at "log jam" on road & $39^{\circ} 30^{\prime} 48.888^{\prime \prime}$ & $105^{\circ} 49^{\prime} 22.224^{\prime \prime}$ \\
HC-1990 & 1990 & HCG downstream of possible inflows & $39^{\circ} 30^{\prime} 45.864^{\prime \prime}$ & $105^{\circ} 49^{\prime} 20.028^{\prime \prime}$ \\
HC-2015 & 2015 & RBI - drains ferricrete & $39^{\circ} 30^{\prime} 45.108^{\prime \prime}$ & $105^{\circ} 49^{\prime} 19.884^{\prime \prime}$ \\
HC-2119 & 2119 & HCG end of study reach & $39^{\circ} 30^{\prime} 42.264^{\prime \prime}$ & $105^{\circ} 49^{\prime} 18.732^{\prime \prime}$ \\
\hline
\end{tabular}

\section{Purpose and Scope}

The purpose of this report is to present water-chemistry data from surface- and ground-water investigations conducted between 2003 and 2006 in Handcart Gulch, Colorado. Use of these data will aid in quantification and characterization of the processes that contribute to the natural conditions of low $\mathrm{pH}$ waters found in this and other unmined alpine watersheds. Data presented in this report include field measurements of $\mathrm{pH}$, specific conductance, dissolved oxygen, Eh, and temperature, and laboratory determinations of the concentrations of major inorganic and selected trace element constituents. In addition, oxygen, hydrogen, and sulfur stable isotopic compositions of surface- and ground-water are reported.

\section{Physical Description of the Study Area}

Handcart Gulch drains approximately $7.9 \mathrm{~km}^{2}$ of the Colorado Front Range, southeast of Montezuma, Colorado (fig. 1). This region is part of the Southern Rocky Mountain physiographic province. The study area within Handcart Gulch is located in the upper 2-3 km of the watershed, encompassing approximately $4.7 \mathrm{~km}^{2}$ and ranging in elevation from 3,815 $\mathrm{m}$ at Handcart Peak to 3,300 $\mathrm{m}$ at the downstream end. 


\section{Geology}

Handcart Gulch lies in the southeastern portion of the Montezuma Mining District (fig. 1). The bedrock geology consists of Precambrian gneisses, schists, amphibolites, and granites that have been intruded by a series of Tertiary-age stocks and veins. The largest and most well-studied stock in the district is the Montezuma stock, which is predominantly porphyritic quartz monzonite in composition but ranges to granite apalite (Neuerburg and others, 1974). Surface geology of Handcart Gulch was mapped by Lovering (1935) and primarily consists of quartz-biotite-sillimanite schists and gneisses, as well as hornblende gneisses. Small quartz monzonite porphyries crop out near Webster Pass and Red Cone. Along the valley floor much of the stream bed lies in ferricrete, ironoxide cemented alluvial and colluvial deposits. Another important feature of Handcart Gulch is the presence of a rock glacier that lies below the Continental Divide (elevation $3,690 \mathrm{~m}$ ) and above the trunk stream (elevation 3,375 m) on the norteast side of the upper watershed.

The Montezuma Mining District has a long mining history starting with the initial discovery of silver in 1864 (Lovering, 1935). Metals mined include silver, lead, zinc, and copper, and ore minerals include galena, sphalerite, and tennantite-tetrahedrite (Botinelly, 1979). Molybdenite is also associated with the Tertiary porphyry stocks. Because of the proximity to the Climax deposit near Leadville, this district has been explored for molybdenum mineralization. Within the upper portion of Handcart Gulch, no mining has occurred with the exception of one small adit with a waste-rock pile of approximately $10 \mathrm{~m}^{3}$.

\section{Climate and Vegetation}

In this region surface water is fed by snowmelt, rainfall, and ground water. At higher elevations in the Southern Rocky Mountains most of the precipitation falls in the winter and spring forming the seasonal snowpack (Ingersoll, 2000). Although there is no meteorological station in Handcart Gulch, an adjacent watershed, Jackwacker Gulch, has a SNOwpack TELemetry (SNOTEL) station maintained by the U.S. Department of Agriculture - Natural Resources Conservation Service. Jackwhacker Gulch is located approximately $5 \mathrm{~km}$ northeast of Handcart Gulch and the station elevation is below timberline at 3,341 $\mathrm{m}$. During the SNOTEL period of record from 1998 to 2006 the 
maximum-recorded temperature was $26.7^{\circ} \mathrm{C}$ on July 2, 2002 with a minimum temperature of $-31^{\circ} \mathrm{C}$ on March 3, 2002. The average high temperature was $16.2^{\circ} \mathrm{C}$, and average low temperature was $-23.4^{\circ} \mathrm{C}$. Precipitation in Handcart Gulch averages $34.8 \mathrm{~cm}$ and primarily falls as snow (Kahn, 2005). Vegetation type is controlled primarily by climate, soil composition, and topography. The upper part of the study area lies above timberline within the tundra climate zones. The lower part of the study area lies within the subalpine climate zone.

\section{Acknowledgments}

We appreciate the generosity of Mineral Systems, Inc. for providing access to the deep boreholes within the study area and the cooperation with the U.S. Forest Service and the Colorado Geological Survey. During the tracer injection study, we appreciate and recognize the assistance of Katherine Walton-Day, Rob Dixon, and Richard Wanty of the USGS and volunteer Margaret G. Walton. We thank Michele Tuttle and Seth Mueller of the USGS for their constructive comments during the preparation and review of this report.

\section{Methods}

\section{Sampling Sites}

During the field seasons of 2001 and 2002 four mineral exploration boreholes were drilled by Mineral Systems Inc. in the upper portion of Handcart Gulch (fig. 2). These boreholes were drilled to at least $455 \mathrm{~m}$ below the surface and were offered to the USGS for use in long-term research. Subsequently, three of these boreholes were logged, cased, and made assessable for ground-water sampling (Caine and others, 2006). During the field season of 2003, nine additional shallow wells (3-52 m) were drilled along the Handcart Gulch stream by the USGS (fig. 2).

Surface water samples collected during the August 6, 2003 tracer-injection study were located along a 2-km reach of the Handcart Gulch trunk stream (fig. 3). Two days prior to sample collection, a reconnaissance of the study reach was performed. Sample sites were selected and marked; their distance downstream of the most upstream water in Handcart Gulch, the outflow from the upper lobe of the rock glacier, were determined using a portable global positioning system (GPS, Garmin 12C, NAD27). Latitude and 
longitude of the sampling sites were acquired at this time. Transport sites, labeled " $\mathrm{T}$ " (table 2), are where numerous samples are collected to determine transport characteristics of the stream. Sample sites were selected upstream and downstream from visible inflows and other features that could affect water quality. Twenty-three surface inflows (tributaries, springs, and seeps) were sampled.

\section{Water-Chemistry Sampling}

Between August 2003 and September 2005 water-chemistry samples were collected periodically from wells in Handcart Gulch. On August 6, 2003, 50 surface-water samples were collected during a stream-tracer study. In addition two surface-water samples were collected September 9, 2005 and one on March 17, 2006.

Before sampling of water in shallow wells, the static water level was measured, the wells were pumped for approximately twenty minutes, and $\mathrm{pH}$, specific conductance, and temperature were monitored until they were stable. Deeper wells (WP1 and WP2) were sampled using a tripod and teflon bailer. On-site measurements of $\mathrm{pH}$, specific conductance, temperature, and dissolved oxygen were obtained utilizing a flow-through cell, or were measured from an aliquot of sample water. At each site the $\mathrm{pH}$ electrode was calibrated using two buffers that bracketed the measured $\mathrm{pH}$ and thermally equilibrated with the water sample. At selected sites Eh was measured. Samples were filtered on site through either a disposable capsule filter having a nominal pore size of $0.45 \mu \mathrm{m}$ or through a syringe filter having a pore size of $0.45 \mu \mathrm{m}$. In this report, constituent concentrations measured in filtered subsamples (FA) are called "dissolved," and constituent concentrations in unfiltered subsamples (RA) are called "total recoverable."

Several sample splits were collected for determination of concentrations of inorganic constituents, redox species, and dissolved organic carbon (DOC). Container preparation and stabilization of filtered samples are summarized in table 3. Samples for the determination of concentrations of cations and trace metals ( $\mathrm{As}, \mathrm{Al}, \mathrm{B}, \mathrm{Ba}, \mathrm{Be}, \mathrm{Bi}, \mathrm{Ca}, \mathrm{Cd}, \mathrm{Ce}, \mathrm{Co}, \mathrm{Cr}, \mathrm{Cs}$, $\mathrm{Cu}$, Dy, Er, Eu, Fe, Gd, Hf, Ho, K, La, Li, Lu, Mg, Mn, Mo, Na, Nd, Ni, Pb, Pr, Rb, Re, Sb, $\mathrm{Se}, \mathrm{SiO}_{2}, \mathrm{Sm}, \mathrm{Sr}, \mathrm{Ta}, \mathrm{Tb}, \mathrm{Te}, \mathrm{Th}, \mathrm{Tl}, \mathrm{Tm}, \mathrm{U}, \mathrm{V}, \mathrm{W}, \mathrm{Y}, \mathrm{Yb}, \mathrm{Zn}$, and $\mathrm{Zr}$ ), major anions (Br, Cl, $\mathrm{F}, \mathrm{NO}_{3}$, and $\mathrm{SO}_{4}$ ), alkalinity, and $\mathrm{DOC}$ were filtered and stabilizing reagents were added when necessary. Sample bottles were pre-rinsed with filtered water prior to sample collection. Samples were collected for the determination of the isotopic composition of 
dissolved sulfate-sulfur isotopes $\left(\delta^{34} \mathrm{~S}\right.$ and $\left.\delta^{18} \mathrm{O}\right)$ and water isotopes $\left(\delta^{2} \mathrm{H}\right.$ and $\left.\delta^{18} \mathrm{O}\right)$ during selected samplings. Delta notation $(\delta)$ is used to describe the isotopic concentration of water and sulfate isotopes. In delta notation, the ratio of the heavy and light isotope is compared to that of a reference standard (Clark and Fritz, 1999).

Table 3. Sample container preparation and stabilization methods for samples.

[ $\mathrm{HCl}$, hydrochloric acid; $\mathrm{HNO}_{3}$, nitric acid; $\mathrm{N}$, normal; v/v, volume per volume; \%, percent]

\begin{tabular}{|c|c|c|}
\hline Sample type(s) & Storage container and preparation & Stabilization treatment \\
\hline $\begin{array}{l}\text { Cations and trace metals } \\
\text { (Al, } \mathrm{As}, \mathrm{B}, \mathrm{Ba}, \mathrm{Be}, \mathrm{Bi}, \mathrm{Ca}, \mathrm{Cd}, \mathrm{Ce} \text {, } \\
\mathrm{Co}, \mathrm{Cr}, \mathrm{Cs}, \mathrm{Cu}, \mathrm{Dy}, \mathrm{Er}, \mathrm{Eu}, \mathrm{Fe}, \mathrm{Gd} \text {, } \\
\mathrm{Hf}, \mathrm{Ho}, \mathrm{K}, \mathrm{La}, \mathrm{Li}, \mathrm{Lu}, \mathrm{Mg}, \mathrm{Mn} \text {, } \\
\mathrm{Mo}, \mathrm{Na}, \mathrm{Nd}, \mathrm{Ni}, \mathrm{Pb}, \mathrm{Pr}, \mathrm{Rb}, \mathrm{Re}, \mathrm{Sb} \text {, } \\
\mathrm{Se}, \mathrm{SiO}_{2}, \mathrm{Sm}, \mathrm{Sr}, \mathrm{Ta}, \mathrm{Tb}, \mathrm{Te}, \mathrm{Th} \text {, } \\
\mathrm{Tl}, \mathrm{Tm}, \mathrm{U}, \mathrm{V}, \mathrm{W}, \mathrm{Y}, \mathrm{Yb}, \mathrm{Zn} \text {, and } \\
\mathrm{Zr} \text { ) }\end{array}$ & $\begin{array}{l}\text { Polyethylene bottles, soaked in 5\% } \\
\mathrm{HNO}_{3} \text { and rinsed } 3 \text { times with } \\
\text { distilled water }\end{array}$ & $\begin{array}{l}1 \%(\mathrm{v} / \mathrm{v}) \text { concentrated redistilled or } \\
\text { Ultrex } 7.7 \mathrm{~N} \mathrm{HNO}_{3} \text { added }\end{array}$ \\
\hline $\begin{array}{l}\text { Iron redox species } \\
(\mathrm{Fe}(\mathrm{T}), \mathrm{Fe}(\mathrm{II}))\end{array}$ & $\begin{array}{l}\text { Opaque polyethylene bottles, } \\
\text { soaked in } 5 \% \mathrm{HCl} \text { and rinsed } 3 \\
\text { times with distilled water }\end{array}$ & $\begin{array}{l}1 \%(\mathrm{v} / \mathrm{v}) \text { redistilled } 6 \mathrm{~N} \text { or Omni } \\
\text { 1:1 trace-metal grade } \mathrm{HCl} \\
\text { added }\end{array}$ \\
\hline $\begin{array}{l}\text { Alkalinity and major anions }(\mathrm{Br} \text {, } \\
\left.\mathrm{Cl}, \mathrm{F}, \mathrm{HCO}_{3}, \mathrm{NO}_{3} \text {, and } \mathrm{SO}_{4}\right)\end{array}$ & $\begin{array}{l}\text { Polyethylene bottles filled with } \\
\text { distilled water and allowed to } \\
\text { stand for } 24 \text { hours, then rinsed } 3 \\
\text { times with distilled water }\end{array}$ & None \\
\hline Dissolved organic carbon (DOC) & Baked glass bottle & None \\
\hline $\begin{array}{l}\text { Oxygen and sulfur isotopes of } \\
\text { dissolved sulfate }\left({ }^{18} \mathrm{O} \text { and }{ }^{34} \mathrm{~S}\right)\end{array}$ & $\begin{array}{l}\text { Polyethylene bottles filled with } \\
\text { distilled water and allowed to } \\
\text { stand for } 24 \text { hours, then rinsed } 3 \\
\text { times with distilled water }\end{array}$ & None \\
\hline Water isotopes $\left({ }^{18} \mathrm{O}\right.$ and $\left.{ }^{2} \mathrm{H}\right)$ & Glass bottle & None \\
\hline
\end{tabular}

On August 6, 2003 surface-water samples were collected during a LiBr tracerinjection study. Detailed description of tracer injection and synoptic sampling can be found in Kimball and others (1999). On August 5, 2003, a continuous injection of a concentrated $\mathrm{LiBr}$ solution was initiated at the upstream end of the study reach (fig. 3). The injection site was located in Handcart Gulch, $34 \mathrm{~m}$ downstream of the outflow from the southwest lobe of the rock glacier, the uppermost surface water in Handcart Gulch. All stream and inflow 
samples were collected on August 6 in 1.8-liter HPDE bottles by submersing the neck of each bottle into the water near the thalweg or at the greatest flow of seeps and springs; sample bottles were triple rinsed with sample water prior to collection. Stream- and inflowwater temperature was measured in situ using an alcohol thermometer. Samples were transported to a central processing area where $125-\mathrm{ml}$ aliquots were prepared for cation and anion analyses. Onsite processing included filtration, measurement of $\mathrm{pH}$ and specific conductance, and preservation of samples for iron speciation. Filtration was completed using tangential-flow units equipped with $0.45 \mu \mathrm{m}$ membranes (FA/FU) and a 10,000Daltons filter membrane (UFA), equivalent to approximately $0.005 \mu \mathrm{m}$ pore size (Alpers and others, 2000). Aliquots for iron speciation were placed in amber bottles and preserved with concentrated $\mathrm{HCl}$ to fix the ratio of ferrous to ferric iron in filtered samples (To and others, 1999). Aliquots for cation analysis were acidified to $\mathrm{pH}<2.0$ with ultrapure nitric acid $\left(\mathrm{HNO}_{3}\right)$.

\section{Laboratory Methods}

All reagents were of a purity at least equal to the reagent-grade standards of the American Chemical Society. Double-distilled de-ionized water and re-distilled acids using a sub-boiling purification technique (Kuehner and others, 1972), were used in all preparations. The methods and detection limit for each analysis are summarized in table 4. USGS standard-reference water samples and blanks were included with each sample suite for inductively-coupled plasma atomic-emission spectroscopy (ICP-AES) and inductively-coupled plasma mass spectrometry (ICP-MS). Major cations ( $\mathrm{Ca}, \mathrm{Mg}, \mathrm{K}$, and $\mathrm{Na}$ ), silica, and selected minor cations for total-recoverable and dissolved samples were determined using a Perkin Elmer Optima 3000TM ICP-AES (Briggs, 2002).

Minor and trace elements (As, Al, B, Ba, Be, Bi, Cd, Ce, Co, Cr, Cs, Cu, Dy, Er, Eu, Gd, Hf, Ho, La, Li, Lu, Mn, Mo, Nd, Ni, Pb, Pr, Rb, Re, Sb, Se, Sm, Sr, Ta, Tb, Te, Th, Tl, Tm, U, V, W, Y, Yb, Zn, and Zr) for total-recoverable and dissolved samples were analyzed with the ICP-MS using a method developed by the USGS (Meier and others, 1994; Lamothe and others, 2002). This method is used to directly determine the elements in the water samples without need for any pre-concentration or dilution. Elemental detection limits are in the sub-parts per billion range (table 4), and the working linear range is six or more orders of magnitude. 
Table 4. Methods of analysis and detection limits.

[mg/L, milligram per liter; $\mu \mathrm{g} / \mathrm{L}$, microgram per liter; IC, ion chromatography; ICP-MS, inductively coupled plasma-mass spectrometry; ICP-AES, inductively coupled plasma-atomic emission spectroscopy]

\begin{tabular}{|c|c|c|c|c|c|}
\hline Element & Detection limit & Method & Element & Detection limit & Method \\
\hline $\mathrm{Ag}$ & $3 \mu \mathrm{g} / \mathrm{L}$ & ICP-MS & $\mathrm{Mn}$ & $0.2 \mu \mathrm{g} / \mathrm{L}$ & ICP-MS \\
\hline $\mathrm{Al}$ & $10 \mu \mathrm{g} / \mathrm{L}$ & ICP-AES & Mo & $2 \mu \mathrm{g} / \mathrm{L}$ & ICP-MS \\
\hline $\mathrm{Al}$ & $2 \mu \mathrm{g} / \mathrm{L}$ & ICP-MS & $\mathrm{Na}$ & $0.1 \mathrm{mg} / \mathrm{L}$ & ICP-AES \\
\hline As & $1 \mu \mathrm{g} / \mathrm{L}$ & ICP-MS & $\mathrm{Nb}$ & $0.2 \mu \mathrm{g} / \mathrm{L}$ & ICP-MS \\
\hline $\mathrm{Ba}$ & $1 \mu \mathrm{g} / \mathrm{L}$ & ICP-AES & $\mathrm{Nd}$ & $0.01 \mu \mathrm{g} / \mathrm{L}$ & ICP-MS \\
\hline $\mathrm{Ba}$ & $0.2 \mu \mathrm{g} / \mathrm{L}$ & ICP-MS & $\mathrm{Ni}$ & $0.4 \mu \mathrm{g} / \mathrm{L}$ & ICP-MS \\
\hline $\mathrm{Be}$ & $0.05 \mu \mathrm{g} / \mathrm{L}$ & ICP-MS & $\mathrm{NO}_{3}$ & $0.1 \mathrm{mg} / \mathrm{l}$ & IC \\
\hline $\mathrm{Bi}$ & $0.2 \mu \mathrm{g} / \mathrm{L}$ & ICP-MS & $\mathrm{P}$ & $10 \mu \mathrm{g} / \mathrm{L}$ & ICP-MS \\
\hline $\mathrm{Br}$ & 0.03 & IC & $\mathrm{Pb}$ & $0.05 \mu \mathrm{g} / \mathrm{L}$ & ICP-MS \\
\hline $\mathrm{Ca}$ & $0.1 \mathrm{mg} / \mathrm{L}$ & ICP-AES & $\operatorname{Pr}$ & $0.01 \mu \mathrm{g} / \mathrm{L}$ & ICP-MS \\
\hline $\mathrm{Cd}$ & $0.02 \mu \mathrm{g} / \mathrm{L}$ & ICP-MS & $\mathrm{Rb}$ & $0.01 \mu \mathrm{g} / \mathrm{L}$ & ICP-MS \\
\hline $\mathrm{Ce}$ & $0.01 \mu \mathrm{g} / \mathrm{L}$ & ICP-MS & $\mathrm{Sb}$ & $0.3 \mu \mathrm{g} / \mathrm{L}$ & ICP-MS \\
\hline $\mathrm{Cl}$ & $0.1 \mathrm{mg} / \mathrm{l}$ & IC & $\mathrm{Sc}$ & $0.6 \mu \mathrm{g} / \mathrm{L}$ & ICP-MS \\
\hline Co & $0.02 \mu \mathrm{g} / \mathrm{L}$ & ICP-MS & $\mathrm{Se}$ & $1 \mu \mathrm{g} / \mathrm{L}$ & ICP-MS \\
\hline $\mathrm{Cr}$ & $1 \mu \mathrm{g} / \mathrm{L}$ & ICP-MS & $\mathrm{SiO}_{2}$ & $0.1 \mathrm{mg} / \mathrm{L}$ & ICP-AES \\
\hline Cs & $0.02 \mu \mathrm{g} / \mathrm{L}$ & ICP-MS & $\mathrm{SO}_{4}$ & $0.05 \mathrm{mg} / \mathrm{l}$ & IC \\
\hline $\mathrm{Cu}$ & $0.5 \mu \mathrm{g} / \mathrm{L}$ & ICP-MS & $\mathrm{Sm}^{4}$ & $0.01 \mu \mathrm{g} / \mathrm{L}$ & ICP-MS \\
\hline Dy & $0.005 \mu \mathrm{g} / \mathrm{L}$ & ICP-MS & $\mathrm{Sr}$ & $1 \mu \mathrm{g} / \mathrm{L}$ & ICP-AES \\
\hline $\mathrm{Er}$ & $0.005 \mu \mathrm{g} / \mathrm{L}$ & ICP-MS & $\mathrm{Sr}$ & $0.5 \mu \mathrm{g} / \mathrm{L}$ & ICP-MS \\
\hline $\mathrm{Eu}$ & $0.005 \mu \mathrm{g} / \mathrm{L}$ & ICP-MS & $\mathrm{Ta}$ & $0.02 \mu \mathrm{g} / \mathrm{L}$ & ICP-MS \\
\hline $\mathrm{F}$ & $0.1 \mathrm{mg} / \mathrm{l}$ & IC & $\mathrm{Tb}$ & $0.005 \mu \mathrm{g} / \mathrm{L}$ & ICP-MS \\
\hline $\mathrm{Fe}$ & $20 \mu \mathrm{g} / \mathrm{L}$ & ICP-AES & $\mathrm{Te}$ & $0.1 \mu \mathrm{g} / \mathrm{L}$ & ICP-MS \\
\hline $\mathrm{Fe}(\mathrm{T})$ & $2 \mu \mathrm{g} / \mathrm{L}$ & FerroZine & Th & $0.2 \mu \mathrm{g} / \mathrm{L}$ & ICP-MS \\
\hline $\mathrm{Fe}$ (II) & $2 \mu \mathrm{g} / \mathrm{L}$ & FerroZine & $\mathrm{Ti}$ & $0.5 \mu \mathrm{g} / \mathrm{L}$ & ICP-MS \\
\hline $\mathrm{Ga}$ & $0.05 \mathrm{vg} / \mathrm{L}$ & ICP-MS & $\mathrm{Tl}$ & $0.1 \mu \mathrm{g} / \mathrm{L}$ & ICP-MS \\
\hline $\mathrm{Gd}$ & $0.005 \mu \mathrm{g} / \mathrm{L}$ & ICP-MS & $\mathrm{Tm}$ & $0.005 \mu \mathrm{g} / \mathrm{L}$ & ICP-MS \\
\hline $\mathrm{Ge}$ & $0.02 \mu \mathrm{g} / \mathrm{L}$ & ICP-MS & $\mathrm{U}$ & $0.1 \mu \mathrm{g} / \mathrm{L}$ & ICP-MS \\
\hline Ho & $0.005 \mu \mathrm{g} / \mathrm{L}$ & ICP-MS & V & $0.5 \mu \mathrm{g} / \mathrm{L}$ & ICP-MS \\
\hline $\mathrm{K}$ & $30 \mu \mathrm{g} / \mathrm{L}$ & ICP-MS & $\mathrm{W}$ & $0.5 \mu \mathrm{g} / \mathrm{L}$ & ICP-MS \\
\hline $\mathrm{La}$ & $0.01 \mu \mathrm{g} / \mathrm{L}$ & ICP-MS & $\mathrm{Y}$ & $0.01 \mu \mathrm{g} / \mathrm{L}$ & ICP-MS \\
\hline $\mathrm{Li}$ & $0.1 \mu \mathrm{g} / \mathrm{L}$ & ICP-MS & $\mathrm{Yb}$ & $0.005 \mu \mathrm{g} / \mathrm{L}$ & ICP-MS \\
\hline $\mathrm{Lu}$ & $0.1 \mu \mathrm{g} / \mathrm{L}$ & ICP-MS & $\mathrm{Zn}$ & $0.5 \mu \mathrm{g} / \mathrm{L}$ & ICP-MS \\
\hline $\mathrm{Mg}$ & $0.1 \mathrm{mg} / \mathrm{L}$ & ICP-AES & $\mathrm{Zr}$ & $0.2 \mu \mathrm{g} / \mathrm{L}$ & ICP-MS \\
\hline $\mathrm{Mn}$ & $10 \mu \mathrm{g} / \mathrm{L}$ & ICP-AES & & & \\
\hline
\end{tabular}


Concentrations of major anions $\left(\mathrm{Br}, \mathrm{Cl}, \mathrm{F}, \mathrm{NO}_{3}\right.$, and $\left.\mathrm{SO}_{4}\right)$ were determined by ion chromatography (Brinton and others, 1995) using a Dionex 2010i ${ }^{\mathrm{TM}}$ ion chromatograph with $10-\mu \mathrm{L}$ and $50-\mu \mathrm{L}$ sample loops. Standards were prepared from compounds of the highest commercially-available purity. USGS standard reference water samples were used as independent quality control standards. Alkalinity $\left(\mathrm{HCO}_{3}{ }^{-}\right)$was determined using an Orion $960^{\mathrm{TM}}$ autotitrator and standardized $\mathrm{H}_{2} \mathrm{SO}_{4}$ (Barringer and Johnsson, 1989). Samples were diluted as necessary to bring the analyte concentration within the optimal range of the method. DOC concentrations (table 5) were determined by the wet persulfate-oxidation method (Aiken, 1992). Iron (II) redox species and total iron in filtered, $\mathrm{HCl}$-acidified samples were determined using a modification of the FerroZine ${ }^{\mathrm{TM}}$ colorimetric method (Stookey, 1970; To and others, 1999) with a Hewlett Packard $8453^{\mathrm{TM}}$ diode array UV/VIS spectrophotometer.

Table 5. Dissolved organic carbon analyses.

[DOC, dissolved organic carbon; mg/L, milligram per liter]

\begin{tabular}{ccc}
\hline WELL & DATE & DOC (mg/L) \\
\hline HCBW1 & $9 / 8 / 2004$ & 0.3 \\
HCBW3 & $9 / 8 / 2004$ & 0.4 \\
HCFW3 & $9 / 8 / 2004$ & 0.4 \\
WP4 & $9 / 8 / 2004$ & 0.2 \\
\hline
\end{tabular}

Sulfur and oxygen isotopic determinations of dissolved sulfate $\left(\delta^{34} \mathrm{~S}, \delta^{18} \mathrm{O}\right)$ were performed by the USGS Crustal Imaging and Characterization Team Laboratory in Denver, Colo. The sulfate ion was removed from the samples by precipitation as barium sulfate $\left(\mathrm{BaSO}_{4}\right)$ following methods described by Carmody and others (1998). Sulfur-isotopic analyses were done by combustion using continuous-flow methods described by Giesemann and others (1994), with a Carlo Erba NC2500 elemental analyzer coupled to a Finnigan Delta Plus XP mass spectrometer. Values of $\delta^{34} \mathrm{~S}_{\mathrm{SO} 4}$ are relative to the standard Vienna Canyon Diablo Troilite (VCDT) with reproducibility of 0.2 per mil. Oxygen analyses of sulfate were done by pyrolysis with a Finnigan TC/EA coupled to a Finnigan Delta Plus XL mass spectrometer using continuous flow methods modified from Kornexl and others (1999). Values of $\delta^{18} \mathrm{O}$ are relative to Vienna Standard Mean Ocean Water (VSMOW) with reproducibility of 0.4 per mil. 
The oxygen and hydrogen isotopic compositions of water $\left(\delta^{18} \mathrm{O}, \delta^{2} \mathrm{H}\right)$ were also performed by the USGS Crustal Imaging Team Laboratory in Denver, Color. Oxygen isotopic compositions were determined using a Micromass Optima with an automated $\mathrm{CO}_{2}$ equilibration technique adapted from Epstein and Mayeda (1953). Water samples were prepared for hydrogen-isotopic analyses using the Zn-reduction technique (Kendall and Coplen, 1985). The hydrogen analyses were preformed on a Finnigan MAT 252 mass spectrometer. Values of $\delta^{18} \mathrm{O}$ and $\delta^{2} \mathrm{H}$ were relative to VSMOW; they have reproducibility of approximately 0.2 and 1.0 per mil, respectively.

\section{Quality Assurance and Quality Control}

Quality control included replicate samples, field equipment blanks, analyses by alternative methods, and calculation of charge imbalance. Replicate samples were two samples considered to be essentially identical in composition and used to estimate variability in environmental data. These samples were collected immediately following the water-chemistry sample and were pumped from the same collection vessel. Each replicate sample was processed through all the steps of the routine water-chemistry sample using a new filter and clean equipment. Replicate samples were analyzed at the same time, using the same instruments as the other samples collected, during the same sampling trip. Analytical results of replicate samples are included in tables 6, 7, 8, and 9, and follow the corresponding water sample (labeled as duplicate). Most major, minor, and trace element replicate concentrations are within \pm 10 percent of the corresponding water-chemistry sample.

A field equipment blank is a sample prepared using blank (deionized) water that has passed through all the sampling and processing equipment. This type of sample is used to check for the potential contamination of the water-chemistry samples during collection, processing, handling, and analysis. Analytical results are included in tables 6, 7, 8, and 9. Most analytes were below analytical detection limits.

Concentrations of cations were determined by both ICP-AES and ICP-MS, and if concentrations of trace elements were at least three times the detection limit, good agreement between ICP-AES and ICP-MS results was observed (fig. 4). Barium, manganese, and strontium were chosen for this comparison because the range in concentrations of these elements was within the working range of both analytical techniques. 

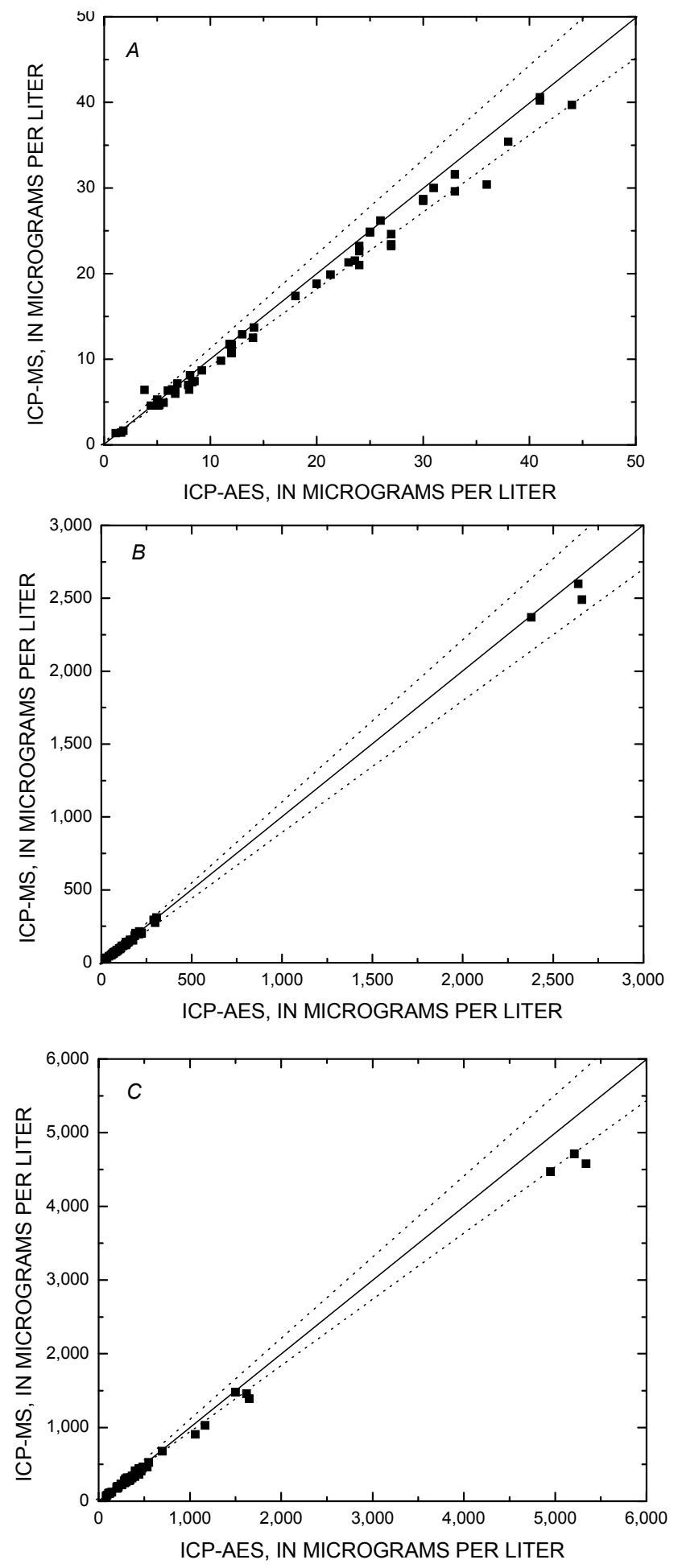

Figure 4. Comparison of analytical results by ICP-AES and ICP-MS with $(A)$ barium concentration, $(B)$ strontium concentration, and $(C)$ manganese concentration. Diagonal line is 1:1 correspondence and dashed lines display 10 percent variation. 
Data for all samples with complete analyses were checked using the computer program WATEQ4F (Ball and Nordstrom, 1991) for charge imbalance (C.I.), using the following calculation:

$$
\text { C.I. }(\text { percent })=\frac{100 *(\text { sum cations }- \text { sum anions })}{(\text { sum cations }+ \text { sum anions }) \div 2}
$$

where sum cations is the sum of the cations in milliequivalents per liter and sum anions is the sum of the anions in milliequivalents per liter. Note that the results of this calculation are twice the value typically reported by an analytical laboratory because the denominator of the equation is the average of the cations and anions rather than the sum of the ions.

The percent C.I. reflects how well the major anions and cations balance and usually is an independent measure of the accuracy of the analytical techniques. The percent C.I. was low ( $<10$ percent) for most samples (tables 6 and 8). Some dilute water samples had charge imbalances that were greater because of analytical imprecisions when determining concentrations at or near the detection limits.

\section{Water Chemistry}

The chemical data for samples collected from the shallow and deep wells are presented in tables 5, 6, and 7, and the chemical data for synoptic samples collected during tracer tests are presented in tables 8 and 9. Results of discharge calculations from the tracer study are presented in table 10. Water-isotopic data are presented in table 11 and dissolved sulfate-isotopic data in table 12 . 
Table 10. Tracer synoptic discharge results.

[m, meters; CFS, cubic feet per second; L/S, liters per second]

\begin{tabular}{cccc}
\hline SITE & DISTANCE (m) & $\begin{array}{c}\text { DISCHARGE, } \\
\text { (CFS) }\end{array}$ & $\begin{array}{c}\text { DISCHARGE, } \\
\text { (L/S) }\end{array}$ \\
\hline HC-114 & 114 & 0.016 & 0.44 \\
HC-160 & 160 & 0.016 & 0.44 \\
HC-209 & 209 & 0.072 & 2.05 \\
HC-294 & 294 & 0.078 & 2.20 \\
HC-395 & 395 & 0.089 & 2.53 \\
HC-511 & 511 & 0.117 & 3.30 \\
HC-556 & 556 & 0.139 & 3.93 \\
HC-574 & 574 & 0.151 & 4.27 \\
HC-596 & 596 & 0.176 & 4.98 \\
HC-635 & 635 & 0.587 & 16.6 \\
HC-754 & 754 & 0.626 & 17.7 \\
HC-873 & 873 & 0.668 & 18.9 \\
HC-959 & 959 & 0.737 & 20.9 \\
HC-999 & 999 & 0.794 & 22.5 \\
HC-1041 & 1041 & 0.810 & 22.9 \\
HC-1143 & 1143 & 0.946 & 26.8 \\
HC-1251 & 1251 & 0.961 & 27.2 \\
HC-1366 & 1366 & 0.982 & 27.8 \\
HC-1496 & 1496 & 0.982 & 27.8 \\
HC-1630 & 1630 & 1.06 & 30.0 \\
HC-1773 & 1773 & 1.09 & 30.8 \\
HC-1871 & 1871 & 1.15 & 32.6 \\
HC-1990 & 1990 & 1.17 & 33.2 \\
HC-2119 & 2119 & 1.27 & 36.1 \\
\hline
\end{tabular}


Table 11. Water isotopic analyses

[DUP, duplicate analysis; --, no data]

\begin{tabular}{cccc}
\hline Site & Date collected & $\boldsymbol{\delta}^{18} \mathbf{0}$ (per mil) & $\delta^{2} \mathbf{H}$ (per mil) \\
\hline HCBW1A & $9 / 7 / 2004$ & -18.1 & -133.0 \\
HCBW1B & $9 / 7 / 2004$ & -18.3 & -133.7 \\
HCBW1C & $9 / 7 / 2004$ & -17.5 & -131.1 \\
HCBW1 & $9 / 12 / 2005$ & -17.9 & -132.3 \\
HCBW2 & $9 / 7 / 2004$ & -18.1 & -134.0 \\
HCBW2 & $9 / 12 / 2005$ & -18.4 & -136.0 \\
HCBW2B & $9 / 12 / 2005$ & -18.1 & -135.0 \\
HCSW2 & $9 / 12 / 2005$ & -17.6 & -132.5 \\
HCSW2 DUP & $9 / 12 / 2005$ & -- & -130.3 \\
HCBW3 & $9 / 7 / 2004$ & -17.6 & -133.0 \\
HCBW3 & $9 / 12 / 2005$ & -18.1 & -132.7 \\
HCBW3 DUP & $9 / 12 / 2005$ & -17.9 & -- \\
HCCW3 & $9 / 7 / 2004$ & -15.2 & -112.4 \\
HCCW3 & $9 / 12 / 2005$ & -16.3 & -118.5 \\
HCFW3 & $9 / 7 / 2004$ & -17.7 & -131.8 \\
HCFW3 & $9 / 12 / 2005$ & -17.8 & -130.5 \\
HCBW4 & $9 / 7 / 2004$ & -17.8 & -134.7 \\
HCBW4 & $9 / 12 / 2005$ & -18.4 & -137.3 \\
HCBW4 DUP & $9 / 7 / 2004$ & -18.6 & -- \\
HCFW5 & $9 / 12 / 2005$ & -17.9 & -136.2 \\
HCBW5 & $9 / 12 / 2005$ & -18.3 & -134.9 \\
HCBW5 DUP & $9 / 12 / 2005$ & -- & -135.3 \\
WP1 & $9 / 10 / 2004$ & -19.3 & -144.9 \\
WP1A & $9 / 13 / 2005$ & -19.5 & -142.9 \\
WP1B & $9 / 13 / 2005$ & -19.6 & -144.7 \\
WP1B DUP & $9 / 13 / 2005$ & -19.6 & -- \\
WP2A & $9 / 8 / 2004$ & -17.9 & -136.0 \\
WP2C & $9 / 8 / 2004$ & -18.8 & -141.0 \\
WP2A & $9 / 13 / 2005$ & -18.4 & -136.8 \\
WP2B & $9 / 13 / 2005$ & -19.1 & -141.2 \\
WP4 & $9 / 8 / 2004$ & -18.5 & -135.5 \\
WP4 & $9 / 13 / 2005$ & -18.6 & -134.3 \\
\hline & & &
\end{tabular}


Table 12. Dissolved sulfate isotopic analyses.

[DUP, duplicate analysis; --, no data]

\begin{tabular}{|c|c|c|c|}
\hline Site & Date Collected & $\delta^{18} 0$ (per mil) & $\delta^{34} S$ (per mil) \\
\hline HCBW1A & $9 / 7 / 2004$ & -8.1 & -1.9 \\
\hline HCBW1B & $9 / 7 / 2004$ & -8.0 & -2.0 \\
\hline HCBW1C & $9 / 7 / 2004$ & -7.6 & -2.0 \\
\hline HCBW1 & $9 / 12 / 2005$ & -7.4 & -1.8 \\
\hline HCBW2 & $9 / 7 / 2004$ & -7.5 & -1.8 \\
\hline HCBW2 & $9 / 7 / 2004$ & -7.5 & -1.7 \\
\hline HCBW2 DUP & $9 / 12 / 2005$ & -7.4 & -1.7 \\
\hline HCBW2 B & $9 / 12 / 2005$ & -8.1 & -1.6 \\
\hline HCSW2 & $9 / 12 / 2005$ & -7.2 & -1.7 \\
\hline HCBW3 & $9 / 7 / 2004$ & -7.3 & -1.9 \\
\hline HCBW3 DUP & $9 / 7 / 2004$ & -7.3 & -1.8 \\
\hline HCBW3 & $9 / 12 / 2005$ & -7.5 & -1.7 \\
\hline HCCW3 & $9 / 7 / 2004$ & -7.1 & -1.6 \\
\hline HCCW3 DUP & $9 / 7 / 2004$ & -7.0 & -- \\
\hline HCCW3 & $9 / 12 / 2005$ & -7.1 & -1.5 \\
\hline HCCW3 DUP & $9 / 12 / 2005$ & -- & -1.5 \\
\hline HCFW3 & 9/7/2004 & -7.1 & -1.8 \\
\hline HCFW3 & $9 / 12 / 2005$ & -7.4 & -1.6 \\
\hline HCBW4 & $9 / 7 / 2004$ & -8.0 & -0.7 \\
\hline HCBW4 & $9 / 12 / 2005$ & -7.2 & 0.0 \\
\hline HCBW5 DUP & $9 / 12 / 2005$ & -8.5 & -- \\
\hline HCFW5 & $9 / 7 / 2004$ & -8.2 & -1.1 \\
\hline HCFW5 & $9 / 12 / 2005$ & -7.9 & -0.9 \\
\hline WP1 & $9 / 10 / 2004$ & -9.6 & 0.2 \\
\hline WP1A & $9 / 13 / 2005$ & -10.1 & -0.1 \\
\hline WP1B & $9 / 13 / 2005$ & -10.0 & -0.1 \\
\hline WP2A & $9 / 8 / 2004$ & -11.5 & -1.6 \\
\hline WP2B & 9/8/2004 & -11.2 & -1.5 \\
\hline WP2B DUP & $9 / 8 / 2004$ & -10.8 & -- \\
\hline WP2C & $9 / 8 / 2004$ & -9.6 & -1.5 \\
\hline WP2A & $9 / 13 / 2005$ & -11.8 & -1.9 \\
\hline WP2A DUP & $9 / 13 / 2005$ & -11.8 & -- \\
\hline WP2B & $9 / 13 / 2005$ & -11.6 & -1.8 \\
\hline WP4 & $9 / 8 / 2004$ & -4.8 & -0.8 \\
\hline WP4 & $9 / 13 / 2005$ & -5.8 & -0.9 \\
\hline HCG1 & $9 / 12 / 2005$ & -6.6 & -1.8 \\
\hline HCG5 & $9 / 12 / 2005$ & -7.6 & -1.5 \\
\hline
\end{tabular}


Ground-water samples are $\mathrm{Ca}-\mathrm{SO}_{4}$ dominated and range in $\mathrm{pH}$ from 2.51 to 6.77. Approximately, 75 percent of the samples have $\mathrm{pH}$ values between 3.3 and 4.3. Samples from well HCBW1 exclusively have $\mathrm{pH}$ values greater than 4.5. In general, with decreasing $\mathrm{pH}$, dissolved sulfate concentration increases (fig. 5). Dissolved trace-metal concentrations are variable with dissolved copper ranging from $<0.5$ to $23,000 \mu \mathrm{g} / \mathrm{L}$ and dissolved zinc from 36 to $582 \mu \mathrm{g} / \mathrm{L}$. A reconnaissance survey of dissolved organic carbon documented that it is quite low in these ground waters, $0.2-0.4 \mathrm{mg} / \mathrm{L}$ (table 5).

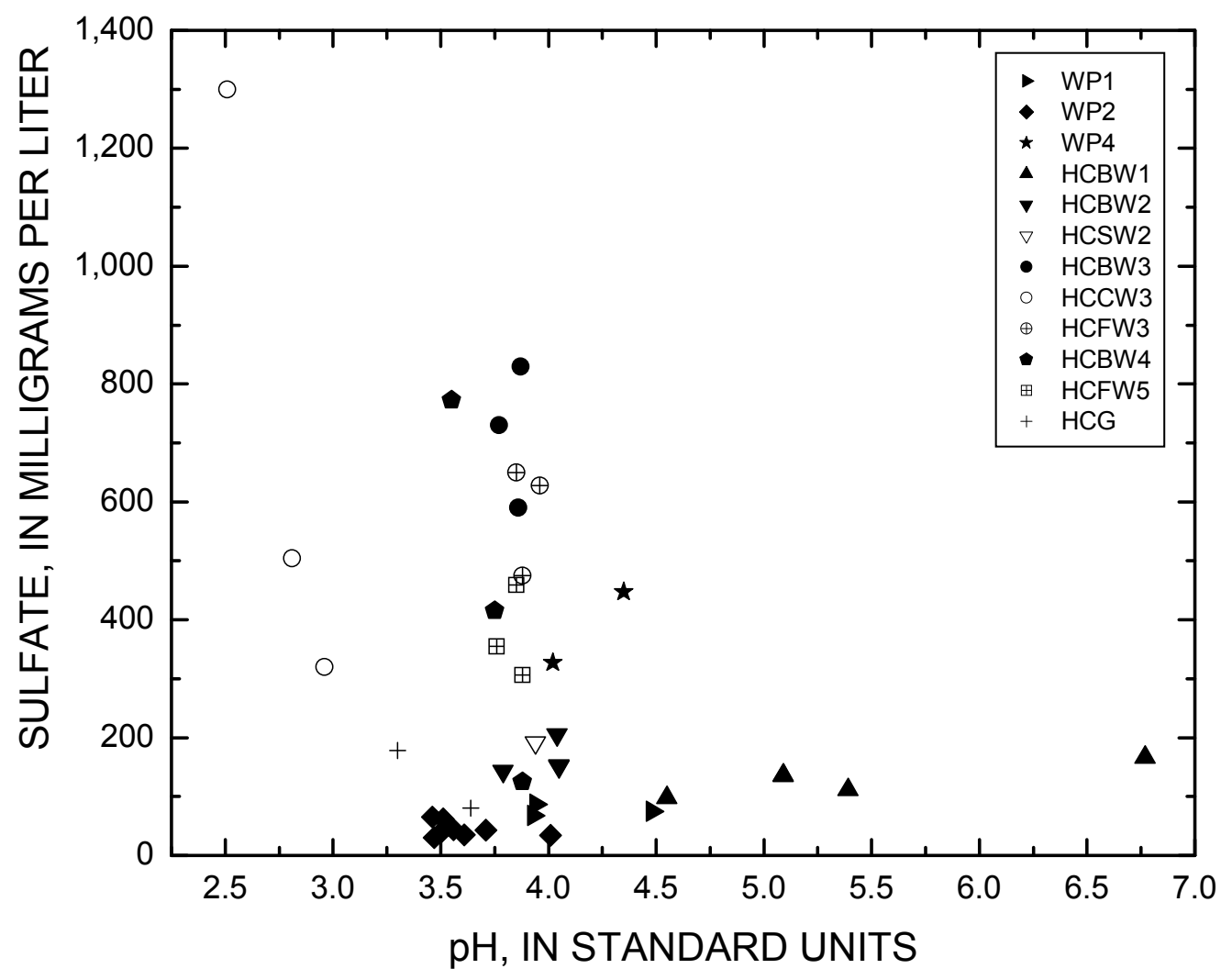

Figure 5. $\mathrm{pH}$ in relation to dissolved sulfate concentration for ground- and surfacewater samples in Handcart Gulch. 
Along the tracer-study reach, the $\mathrm{pH}$ of Handcart Gulch decreased from 3.98 to 3.24, and the $\mathrm{pH}$ of inflows to Handcart Gulch varied from 2.69 to 4.02 (fig. 6). The dissolved sulfate concentration increased by approximately a factor of 10 , from 20.7 to $276 \mathrm{mg} / \mathrm{L}$ (fig. 7). The concentration of sulfate of the inflows was quite variable, 30.0 $1,010 \mathrm{mg} / \mathrm{L}$. Along the tracer-study reach, dissolved iron concentrations increased from 0.091 to $27.2 \mathrm{mg} / \mathrm{L}$, with inflow concentrations varying from 0.110 to $124 \mathrm{mg} / \mathrm{L}$ (fig. 8). The total-recoverable iron concentration is greater than the dissolved-iron concentration for most of the stream samples in the downstream section of the study reach (fig 8), indicating that a fraction of the iron in the water column is colloidal. This is consistent with the observation of fresh-iron precipitates along the stream bed and the occurrence of ferricrete along much of the study reach.

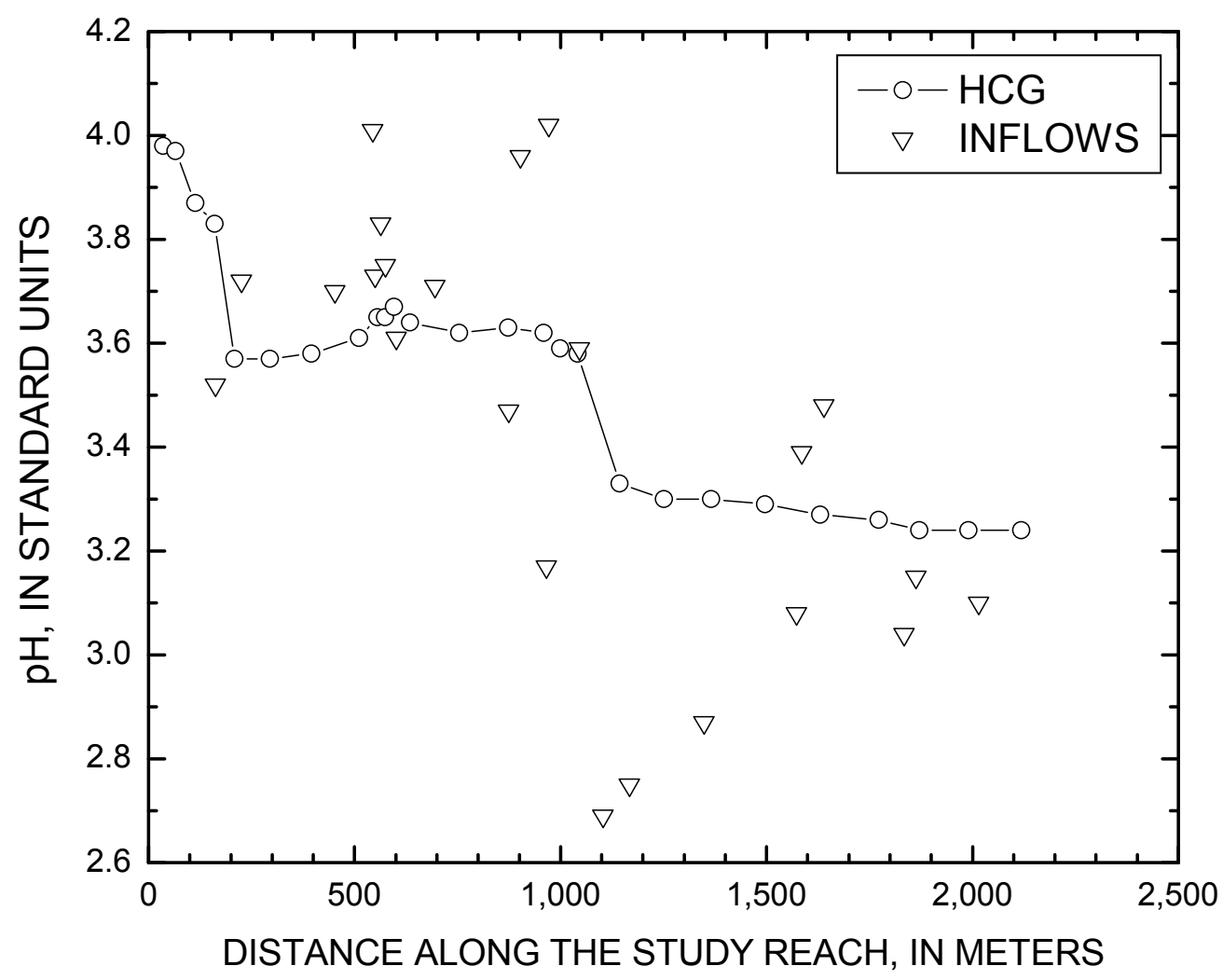

Figure 6. pH as a function of downstream distance for Handcart Gulch. 


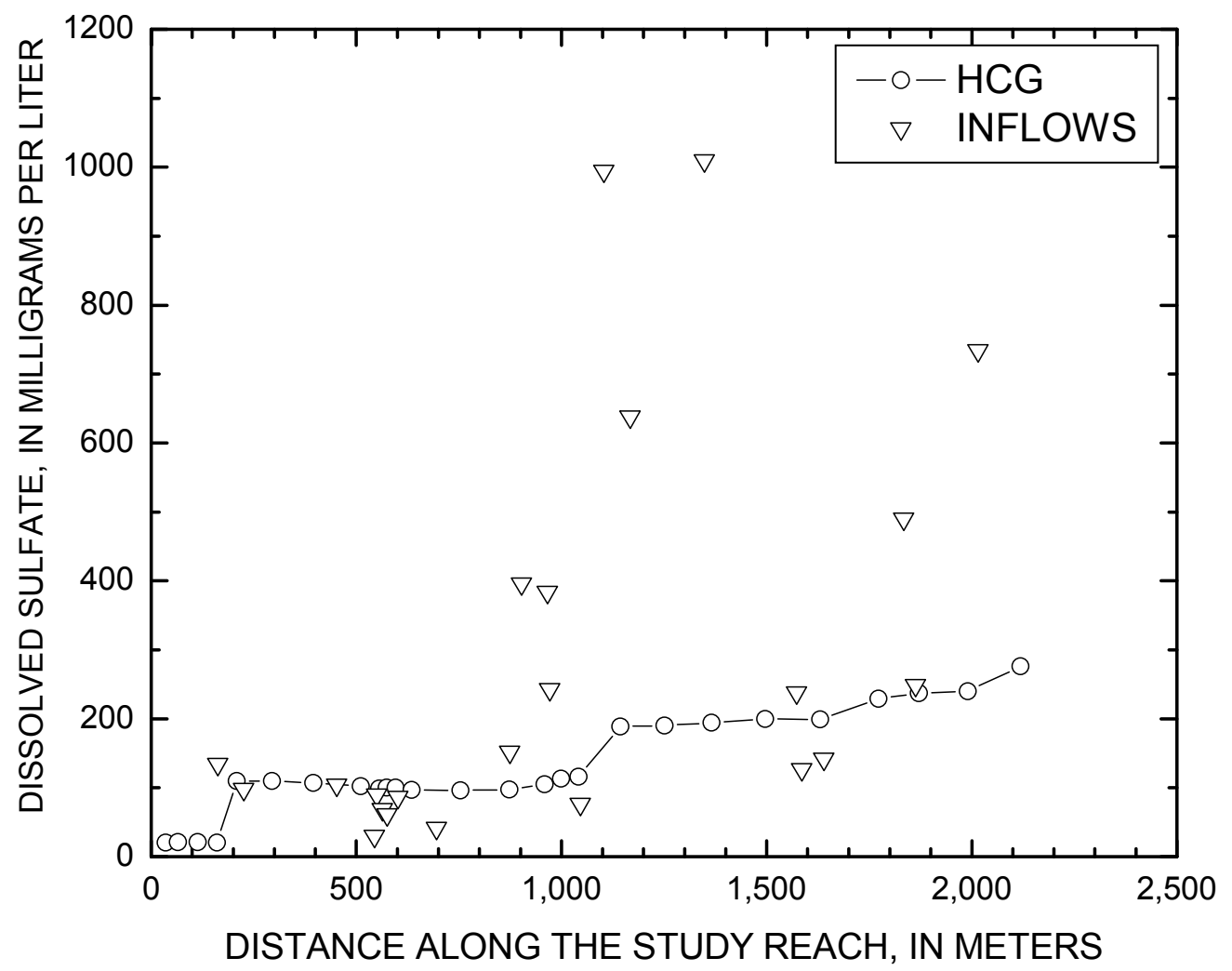

Figure 7. Dissolved sulfate concentration as a function of downstream distance for Handcart Gulch. 


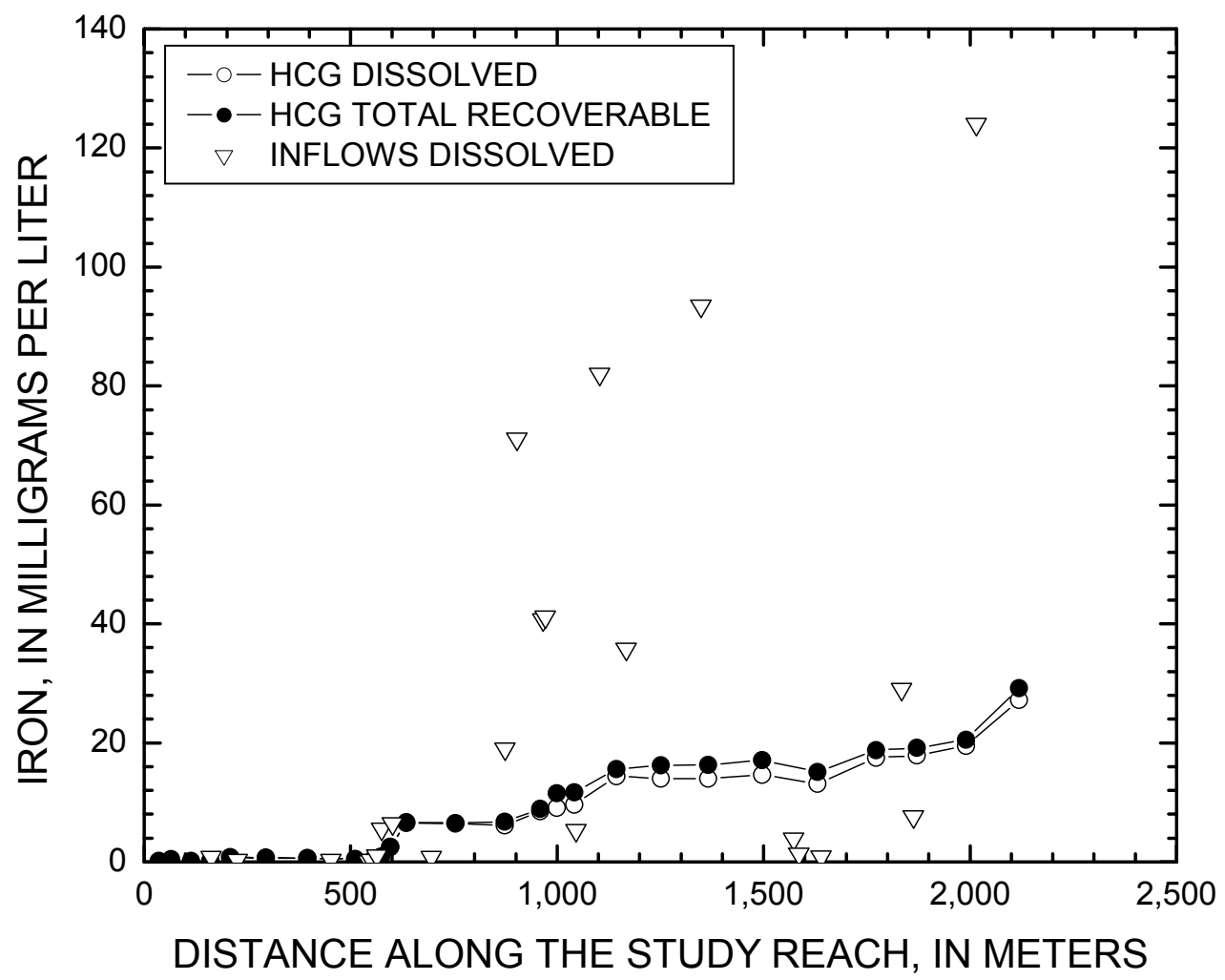

Figure 8. Dissolved and total-recoverable iron concentration as a function of downstream distance for Handcart Gulch.

Dissolved copper concentration along the study reach increased from $<0.010$ to $0.216 \mathrm{mg} / \mathrm{L}$, with a relatively steady increase in the lower 1,000 m (fig. 9). Little difference between the total-recoverable and dissolved fractions was observed, suggesting that most of the copper remained in solution. Dissolved copper concentrations of inflows in the upper $1,000 \mathrm{~m}$ of the study reach are low $(<0.010-0.045 \mathrm{mg} / \mathrm{L})$ compared to inflows in the lower $1,000 \mathrm{~m}(0.149-0.927 \mathrm{mg} / \mathrm{L})$. Dissolved zinc concentrations along the study reach increased from $<0.010$ to $0.173 \mathrm{mg} / \mathrm{L}$, but in contrast to the dissolved copper profile, the zinc profile (fig. 10) displayed a step-like increase at $635 \mathrm{~m}$ just downstream of the confluence of a major tributary entering from the northwest (fig. 3). Water entering Handcart Gulch in the reach between $596 \mathrm{~m}$ and $635 \mathrm{~m}$ tripled the discharge of the trunk stream (4.98-16.6 L/S; table 12 and fig. 11). 


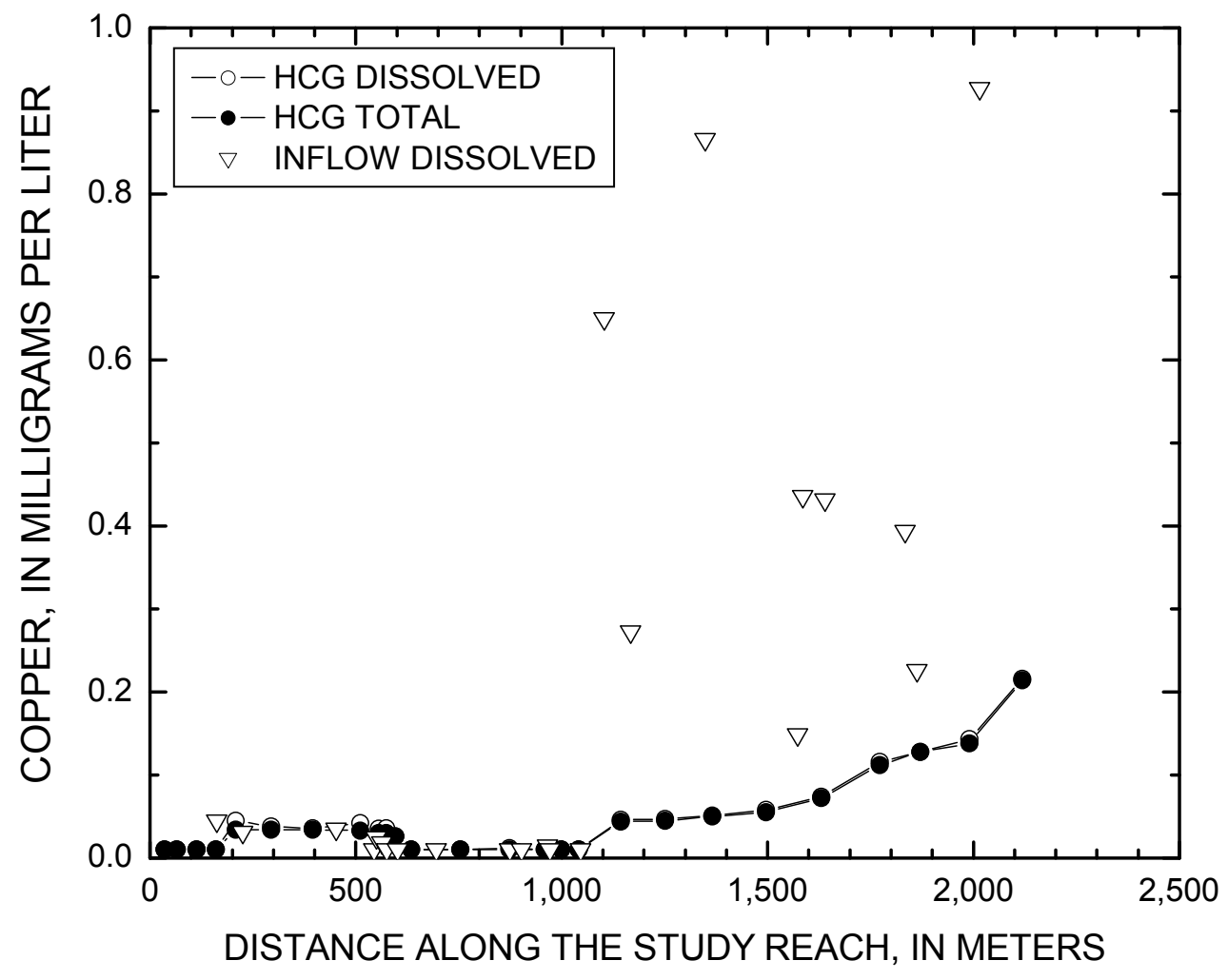

Figure 9. Dissolved and total-recoverable copper concentration as a function of downstream distance for Handcart Gulch. 


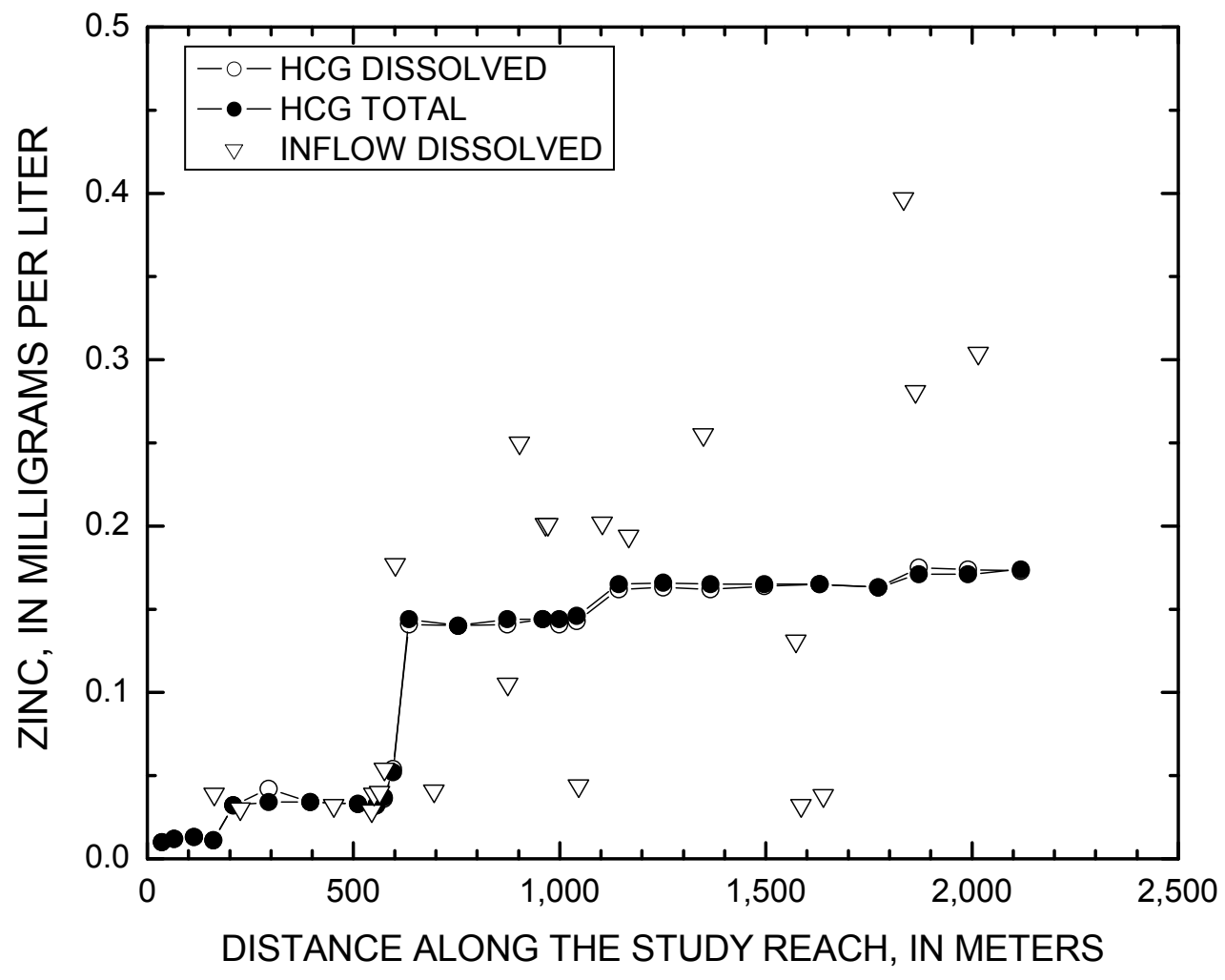

Figure 10. Dissolved and total-recoverable zinc concentration as a function of downstream distance for Handcart Gulch. 


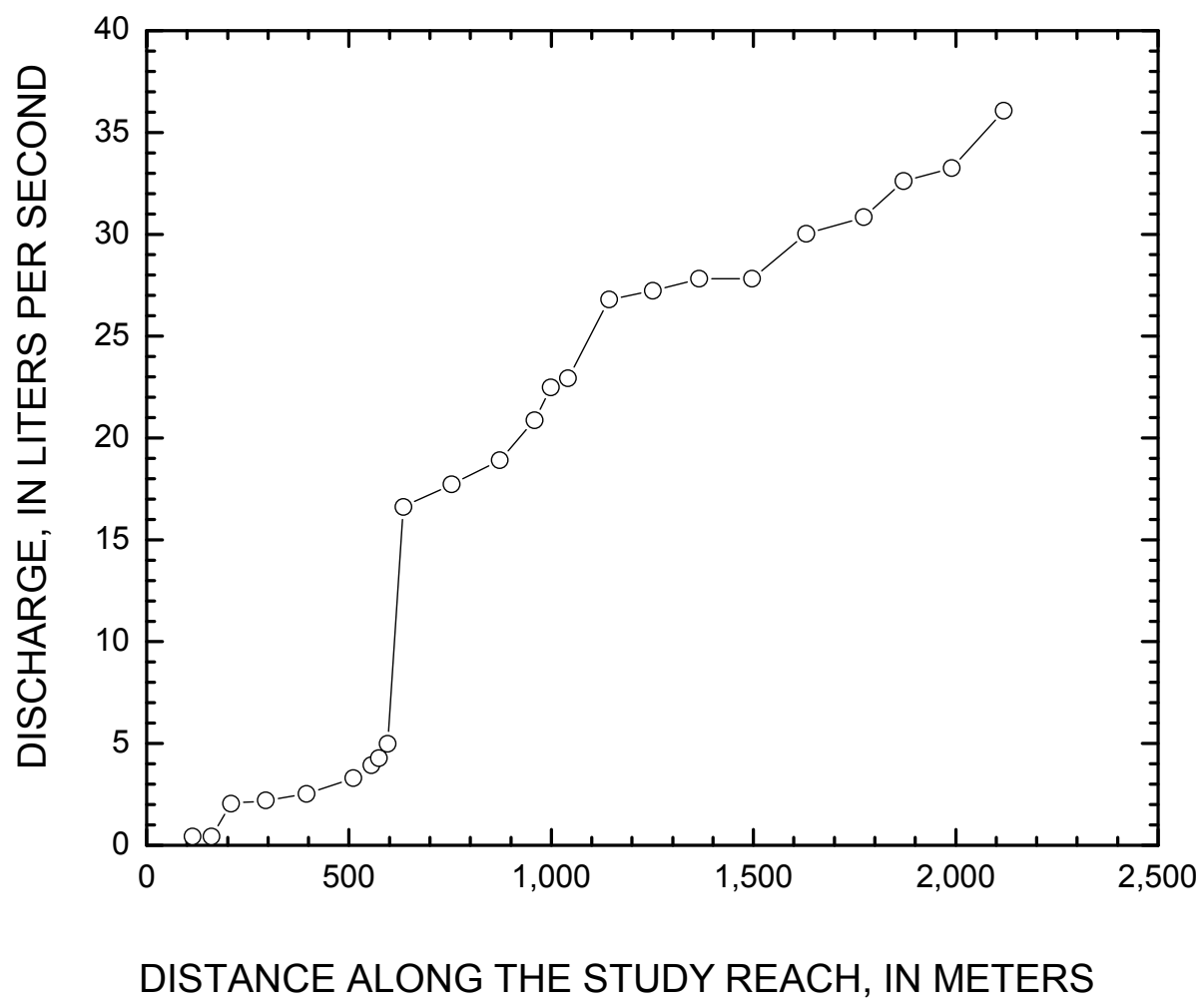

Figure 11. Discharge as a function of downstream distance for Handcart Gulch.

Discharge along the study reach increased from 0.44 to $36.1 \mathrm{~L} / \mathrm{S}$ (table 12, fig. 11). Discharge data was combined with chemistry data to create loading profiles (figs. 12 $A-D)$. Dissolved sulfate, iron, copper and zinc profiles displayed substantial downstream loading increases (fig. $12 A-D$ ). 

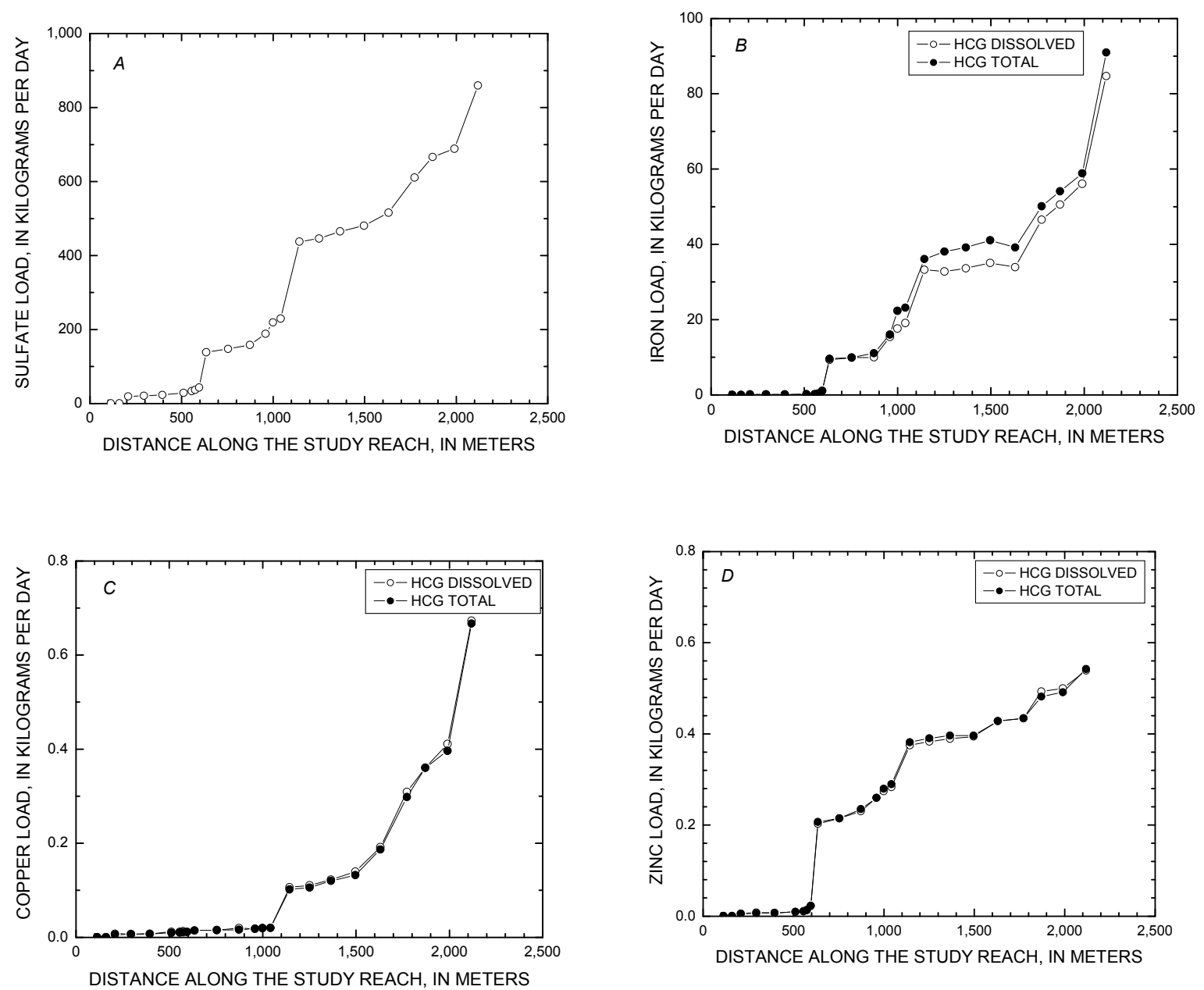

Figure 12. Constituent loads as a function of downstream distance for Handcart Gulch for $(A)$ sulfate, $(B)$ iron, $(C)$ copper, and $(D)$ zinc. 


\section{References Cited}

Aiken, G.R., 1992, Chloride interference in the analysis of dissolved organic carbon by the wet oxidation method: Environmental Science and Technology, v. 26, p. $2435-2439$.

Alpers, C.N., Taylor, H.E., Roth, D.A., Cain, D.J., Ball, J.W., Unruh, D.M., and Dileanis, P.D., 2000, Study design: Field and laboratory methods, in Alpers, C.N., Taylor, H.E., and Domagalski, J.L., eds., Metals transport in the Sacramento River, California, 1996-1997: U.S. Geological Survey Water-Resources Investigations Report 99-4286, p. 19-38.

Ball, J.W., and Nordstrom, D.K., 1991, User's manual for WATEQ4F, with revised thermodynamic data base and test cases for calculating speciation of major, trace, and redox elements in natural waters: U.S. Geological Survey Open-File Report 91-183, 189 p.

Barringer, J.L., and Johnsson, P.A., 1989, Theoretical considerations and a simple method for measuring alkalinity and acidity in low-pH waters by gran titration: U.S. Geological Survey Water-Resources Investigations Report 89-4029, 35 p.

Botinelly, T., 1979, Mineralogy as a guide for exploration in the Montezuma District, central Colorado: U.S. Geological Survey Open-File Report 79-1177, 18 p.

Briggs, P.H., 2002, The determination of twenty-seven elements in aqueous samples by inductively coupled plasma-atomic emission spectrometry, in Taggart, J.E., ed., Analytical methods for chemical analysis of geologic and other materials, U.S. Geological Survey: U.S. Geological Survey Open-File Report 02-223, ch. F, 11 p.

Brinton, T.I., Antweiler, R.C., and Taylor, H.E., 1995, Method for the determination of dissolved chloride, nitrate and sulfate in natural water using ion chromatography: U.S. Geological Survey Open-File Report 95-426, 16 p.

Caine, J.S., Bove, D.J., Manning, A.H., and Verplanck, P.L., 2004, Preliminary characterization of geological controls on groundwater flow and solute transport in an alpine hydrothermal metal deposit: Handcart Gulch, Montezuma Mining District, Colorado Rocky Mountain Front Range: Annual Meeting, Denver, Colorado, Geological Society of America Abstracts with Programs, v. 36, p. 539.

Caine, J.S., Manning, A.H., Verplanck, P.L., Bove, D.J., Kahn, K.G., and Ge, Shemin, 2006, Well construction information, lithologic logs, water level data, and overview of research in the Handcart Gulch, Colorado: An alpine watershed affected by metalliferous hydrothermal alteration: U.S. Geological Survey OpenFile Report 2006-1189, 13 p.

Carmody, R.W., Plummer, L.N., Busenberg, E., and Coplen, T.B., 1998, Methods for collection of dissolved sulfate and sulfide and analysis of their sulfur isotopic composition: U.S. Geological Survey Open-File Report 97-234. 91 p. 
Clark, I.D., and Fritz, Peter, 1999, Environmental Isotopes in Hydrogeology: Boca Raton, Fla.,Lewis Publishers, 328 p.

Epstein, S., and Mayeda, T., 1953, Variations of $\mathrm{O}^{18}$ contents of waters from natural sources: Geochimica et Cosmochimica Acta, v 4, p. 213-224.

Giesemann, A., Jäger, H.J., Norman, A.L., Krouse, H.R., and Brand, W.A., 1994, On-line sulfur-isotope determination using an elemental analyzer coupled to a mass spectrometer: Analytical Chemistry, v. 66, p. 2816-2819.

Ingersoll, G.P., 2000, Snowpack chemistry at selected sites in Colorado and New Mexico during winter 1999-2000: U.S. Geological Survey Open-File Report 00-394, 9 p.

Kahn, K.G., 2005, Analysis of the shallow groundwater system in an alpine basin: Handcart Gulch, Colorado: Master of Science Thesis, University of Colorado, Boulder, $150 \mathrm{p}$.

Kahn, K.G., Caine, J.S., and Ge, Shemin, 2005, Estimating hydraulic properties of complexly fractured and metallically mineralized bedrock in an alpine watershed: Handcart Gulch, Colorado: Geological Society of America Abstracts with Programs, v. 37, n. 7, p. 504.

Kendall, Carol, and Coplen, T.B., 1985, Multisample conversion of water to hydrogen by zinc for stable isotope determination: Analytical Chemistry, v.57, n.7, p. 14371440 .

Kimball, B.A., Nimick, D.A., Gerner, L.J., and Runkel, R.L., 1999, Quantification of metal loading in Fisher Creek by tracer injection and synoptic sampling, Park County, Montana, August 1997: U.S. Geological Survey Water-Resources Investigations Report 99-4119, 40 p.

Kimball, B.A., Runkel, R.L., Bencala, K.E., and Walton-Day, K., 2002, Assessment of metal loads in watersheds affected by acid mine drainage by using tracer injection and synoptic sampling, Cement Creek, Colorado, USA: Applied Geochemistry, v. 17, p. $1183-1207$.

Kornexl, B.E., Gehre, M., Höfling, P., and Werner, R.A., 1999, On-line $\delta^{18} \mathrm{O}$ measurements of organic and inorganic substances: Rapid Communications in Mass Spectrometry, v. 13, p. 1685-1693.

Kuehner, E.C., Alvarez, R., Paulsen, P.J., and Murphy, T.J., 1972, Production and analysis of special high-purity acids purified by sub-boiling distillation: Analytical Chemistry, v. 44, p. 2050-2056.

Lamothe, P.J., Meier, A.L., and Wilson, S.A., 2002, The determination of forty-four elements in aqueous samples by inductively coupled plasma-mass spectrometry, in Taggart, J.E., ed., Analytical methods for chemical analysis of geologic and other materials, U.S. Geological Survey: U.S. Geological Survey Open-File Report 02-223, ch. H, 13 p. 
Lovering, T.S., 1935, Geology and Ore Deposits of the Montezuma Quadrangle Colorado: U.S. Geological Survey Professional Paper 178, 119 p.

Manning, A.H., Caine, J.S., Verplanck, P.L., Bove, D.J., and Landis, G.P., 2004, Insights into groundwater flow in an alpine watershed provided by a coupled heat, mass, and fluid transport model, Handcart Gulch, Colorado: Annual Meeting, Denver, Colorado, Geological Society of America Abstracts with Programs, v. 36, p. 539.

Meier, A.L., Grimes, D.J., and Ficklin, W.H., 1994, Inductively coupled plasma mass spectrometry-A powerful analytical tool for mineral resource and environmental studies [abs], in Carter, L.M.H., Toth, M.I., and Day, W.C., eds., USGS Research on Mineral Resources-1994, Part A-Program and Abstracts, Ninth V.E. McKelvey Forum on Mineral and Energy Resources: U.S. Geological Survey Circular 1103-A, p. 67-68.

Neuerburg, G.J., Botinelly, T., and Watterson, J., 1974, Molybdenite in the Montezuma District of central Colorado: U.S. Geological Survey Circular 0704, 21 pp.

Stookey, L.L., 1970, FerroZine-A new spectrophotometric reagent for iron: Analytical Chemistry, v. 42, p. 779-781.

To, T.B., Nordstrom, D.K., Cunningham, K.M., Ball, J.W., and McCleskey, R.B., 1999, New method for direct determination of dissolved Fe(III) concentrations in acid mine waters: Environmental Science and Technology, v. 33, p. 807-813.

Verplanck, P.L., Nordstrom, D.K., Manning, A.H., Caine, J.S., Plumlee, G.S., Hunt, A.G., and Bove, D.J., 2004, Linking geochemical and hydrologic models of ground water in two Rocky Mountain catchments: Straight Creek, NM and Handcart Gulch, CO: Annual Meeting, Denver, Colorado, Geological Society of America Abstracts with Programs, v. 36, p. 539. 